\title{
Data report: atlas of lithic grain types at Site C0002; reference for petrographic provenance analysis in the Kumano Basin and upper Nankai accretionary prism ${ }^{1}$
}

Sebastian G. Ramirez ${ }^{2}$ and Kitty L. Milliken ${ }^{3}$

\section{Chapter contents}

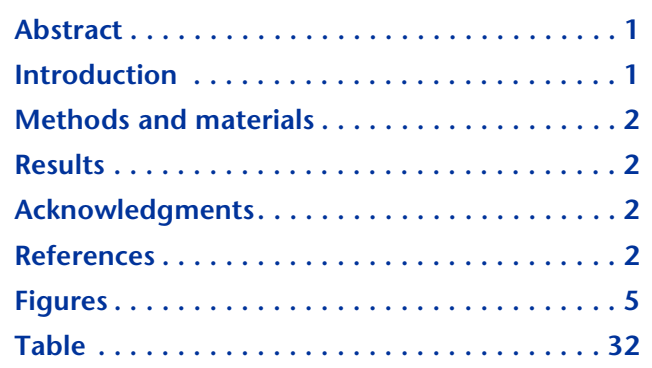

${ }^{1}$ Ramirez, S.G., and Milliken, K.L., 2016. Data report: atlas of lithic grain types at Site C0002; reference for petrographic provenance analysis in the Kumano Basin and upper Nankai accretionary prism. In Strasser, M., Dugan, B., Kanagawa, K., Moore, G.F., Toczko, S., Maeda, L., and the Expedition 338 Scientists, Proceedings of the Integrated Ocean Drilling Program, 338: Yokohama (Integrated Ocean Drilling Program). doi:10.2204/iodp.proc.338.204.2016 ${ }^{2}$ Institute of Geophysics, Jackson School of Geosciences, University of Texas at Austin, Austin TX 78712, USA. Correspondence author: sgramirez@utexas.edu

${ }^{3}$ Bureau of Economic Geology, Jackson School of Geosciences, University of Texas at Austin, Austin TX 78713, USA.

\section{Abstract}

Sand samples collected during Integrated Ocean Drilling Program Expeditions 338 and 315 at Site C0002 show a variety of lithic fragment types. The lithic component in these sediments includes grains of sedimentary, metamorphic, volcanic, and plutonic origin. An atlas of lithic grain types from Site C0002 serves as a useful reference for petrographic provenance analysis in the Kumano Basin and the underlying prism sediments. The relative abundance of monocrystalline mineral grains and grain ratios are subject to textural and diagenetic controls external to provenance. Lithic grains, in particular, provide very specific and reliable information on variations in sediment source.

\section{Introduction}

Lithic grains are polycrystalline particles that can in many cases be identified as belonging to specific parent lithologies. Although monocrystalline grains may have internal textures (e.g., Bernet and Bassett, 2005; Lee et al., 1998), the provenance information in monocrystalline grains (quartz, feldspar, and dense minerals) is primarily derived from their composition, which for feldspars and dense minerals can be modified by dissolution and replacement during diagenesis (e.g., Milliken and Mack, 1990; Milliken, 1988; Morton, 1984). Grain ratios (e.g., quartz-feldspar-lithic fragments) are also subject to control by grain size (Ingersoll et al., 1984), a factor that is not fully removed even by the Gazzi-Dickinson point-count technique that extracts large monocrystals from lithic grains (Milliken et al., 2012; Decker and Helmold, 1985). In lithic fragments themselves, however, provenance information resides mostly in their textures, which are less subject to postdepositional alteration (Milliken, 1988) and unaffected by grain size once a grain is sufficiently large to preserve the texture. Lithic grains are "recognizable fragments of the source terrane" (Decker and Helmold, 1985) and as such constitute an easily accessible and exceptionally reliable type of information on sediment source. Survival of lithic grains during sediment transport is favored in far-distal sands that avoid reworking in coastal depositional systems (Dutton and Loucks, 2010).

The atlas presented here intends to serve as a reference for the lithic grain types observed within the sand-size ( $62 \mu \mathrm{m}$ to $2 \mathrm{~mm}$ ) grain fraction of the Kumano Basin and underlying Nankai accre- 
tionary prism. Our grain identifications draw on materials presented in several published petrography resources (Usman et al., 2014; Fergusson, 2011; Milliken et al., 2007; Underwood and Fergusson, 2005; Fergusson, 2003; Garzanti and Vezzoli, 2003; Marsaglia, 1992; Marsaglia et al., 1992; De Rosa et al., 1986; Taira and Niitsuma, 1986; Scholle, 1979).

\section{Methods and materials}

Core and cuttings sandy sediment samples $\left(10 \mathrm{~cm}^{3}\right)$ were collected through the basin and prism stratigraphy during Integrated Ocean Drilling Program (IODP) Expedition 338 (Strasser et al., 2014). Where possible, intervals with no sample coverage were completed with material recovered during IODP Expedition 315 (see the "Expedition 315 Site C0002" chapter [Expedition 315 Scientists, 2009]). Sampling distribution was $\sim 1$ sample per core/cuttings where available. A total of 99 Miocene-recent samples were obtained.

Semiconsolidated sediments of each sample were fully disaggregated with the help of a sonicator and were wet-sieved using $62 \mu \mathrm{m}$ mesh to isolate the sand-size fraction. Dried sand was impregnated with blue-dyed epoxy and mounted into thin sections. Each sample was stained following the method outlined by Houghton (1980), in which Ca-plagioclase is stained pink, K-feldspar is stained yellow, glass may take one or both colors, and Na-plagioclase remains unstained.

Each sample was studied under a transmitted-light microscope (plane- and cross-polarized modes), and photomicrographs of representative lithic fragments were taken. Unless otherwise indicated, the grain of interest is at the center of the image.

\section{Results}

A total of 162 photomicrographs are included (Figs. F1, F2, F3, F4, F5, F6, F7, F8, F9, F10, F11, F12, F13, F14, F15, F16, F17, F18, F19, F20, F21, F22, F23, F24, F25, F26, F27). The sample number, lithic type, and lithostratigraphic unit of each photographed grain are included in Table T1. Lithic grains were grouped into sedimentary lithic fragments (SRFs) (Figs. F1, F2, F3, F4, F5, F6, F7, F8, F9), volcanic lithic fragments (VRFs) (Figs. F10, F11, F12, F13, F14, F15), plutonic lithic fragments (PRFs) (Figs. F16, F17, F18, F19), and metamorphic lithic fragments (MRFs) (Figs. F20, F21, F22, F23, F24, F25). SRFs were further divided into clay-rich (Figs. F1, F2, F3, F4, F5) and silt-rich (Figs. F6, F7A-F7D) mudstones, sandstones (Fig. F7E-F7F), argillaceous cherts (Fig. F8), and cherts (Fig. F9). VRFs were divided into fel- sitic (Figs. F10, F11), microlitic (Fig. F12), lathwork (Fig. F13), trachytic lathwork (Fig. F14), and pumice (Fig. F15). PRFs, with the exception of K-feldsparquartz intergrowths (Fig. F18), were not divided. MRFs were divided into quartz rich (Fig. F20), quartz-mica rich (Fig. F21), micaceous (Fig. F22), chlorite rich (Fig. F23), epidote rich (Fig. F24), and others (Fig. F25). Petrographic definitions of each of these lithic fragment categories can be found in Marsaglia (1992), Marsaglia et al. (2013), and Milliken et al. (2007).

Grains that are not lithic fragments, such as poorly disaggregated muds (Fig. F26) or postdrilling sulfate precipitates (Fig. F27) were included under the category Artifacts.

\section{Acknowledgments}

The Integrated Ocean Drilling Program provided the samples used for this report. Postexpedition funding awarded to S.G. Ramirez by the Consortium for Ocean Leadership helped support this project. S.G. Ramirez and K.L. Milliken also wish to thank the Expedition 338 Scientists for their help with shipboard sampling.

\section{References}

Bernet, M., and Bassett, K., 2005. Provenance analysis by single-quartz-grain SEM-CL/optical microscopy. Journal of Sedimentary Research, 75(3):492-500. http:// dx.doi.org/10.2110/jsr.2005.038

De Rosa, R., Zuffa, G.G., Taira, A., and Leggett, J.K., 1986. Petrography of trench sands from the Nankai Trough, southwest Japan: implications for long-distance turbidite transportation. Geological Magazine, 123(5):477486. http://dx.doi.org/10.1017/S0016756800035068

Decker, J., and Helmold, K.P., 1985. The effect of grain size on detrital modes: a test of the Gazzi-Dickinson pointcounting method: discussion. Journal of Sedimentary Research, 55(4):618-620. http://archives.datapages.com/data/sepm/journals/v55-58/data/055/ 055004/0618.htm

Dutton, S.P., and Loucks, R.G., 2010. Diagenetic controls on evolution of porosity and permeability in lower Tertiary Wilcox sandstones from shallow to ultradeep (200-6700 m) burial, Gulf of Mexico Basin, U.S.A. Marine and Petroleum Geology, 27(1):69-81. http:// dx.doi.org/10.1016/j.marpetgeo.2009.08.008

Expedition 315 Scientists, 2009. Expedition 315 Site C0002. In Kinoshita, M., Tobin, H., Ashi, J., Kimura, G., Lallemant, S., Screaton, E.J., Curewitz, D., Masago, H., Moe, K.T., and the Expedition 314/315/316 Scientists, Proceedings of the Integrated Ocean Drilling Program, 314/ 315/316: Washington, DC (Integrated Ocean Drilling Program Management International, Inc.). http:// dx.doi.org/10.2204/iodp.proc.314315316.124.2009 
Fergusson, C.L., 2003. Provenance of Miocene-Pleistocene turbidite sands and sandstones, Nankai Trough, Ocean Drilling Program Leg 190. In Mikada, H., Moore, G.F., Taira, A., Becker, K., Moore, J.C., and Klaus, A. (Eds.), Proceedings of the Ocean Drilling Program, Scientific Results, 190/196: College Station, TX (Ocean Drilling Program), 1-28. http://dx.doi.org/10.2973/ odp.proc.sr.190196.205.2003

Fergusson, C.L., 2011. Data report: clast counts and petrography of gravels from Site C0007, IODP Expedition 316, Nankai Trough. In Kinoshita, M., Tobin, H., Ashi, J., Kimura, G., Lallemant, S., Screaton, E.J., Curewitz, D., Masago, H., Moe, K.T., and the Expedition 314/315/316 Scientists, Proceedings of the Integrated Ocean Drilling Program, 314/315/316: Washington, DC (Integrated Ocean Drilling Program Management International, Inc.). http://dx.doi.org/10.2204/ iodp.proc.314315316.203.2011

Garzanti, E., and Vezzoli, G., 2003. A classification of metamorphic grains in sands based on their composition and grade. Journal of Sedimentary Research, 73(5):830837. http://dx.doi.org/10.1306/012203730830

Houghton, H.F., 1980. Refined techniques for staining plagioclase and alkali feldspars in thin section. Journal of Sedimentary Research, 50(2):629-631. http://jsedres.geoscienceworld.org/content/50/2/629.abstract

Ingersoll, R.V., Bullard, T.F., Ford, R.L., Grimm, J.P., Pickle, J.D., and Sares, S.W., 1984. The effect of grain size on detrital modes: a test of the Gazzi-Dickinson pointcounting method. Journal of Sedimentary Research, 54(1):103-116. http://dx.doi.org/10.1306/212F83B92B24-11D7-8648000102C1865D

Lee, M.R., Hodson, M.E., and Parsons, I., 1998. The role of intragranular microtextures and microstructures in chemical and mechanical weathering: direct comparisons of experimentally and naturally weathered alkali feldspars. Geochimica et Cosmochimica Acta, 62(16):2771-2788. http://dx.doi.org/10.1016/ S0016-7037(98)00200-2

Marsaglia, K., Milliken, K., and Doran, L., 2013. IODP digital reference for smear slide analysis of marine mud, Part 1: Methodology and atlas of siliciclastic and volcanogenic components. Integrated Ocean Drilling Program Technical Note, 1. http://dx.doi.org/10.2204/ iodp.tn.1.2013

Marsaglia, K.M., 1992. Petrography and provenance of volcaniclastic sands recovered from the Izu-Bonin arc, Leg 126. In Taylor, B., Fujioka, K., et al., Proceedings of the Ocean Drilling Program, Scientific Results, 126: College Station, TX (Ocean Drilling Program), 139-154. http:// dx.doi.org/10.2973/odp.proc.sr.126.124.1992

Marsaglia, K.M., Ingersoll, R.V., and Packer, B.M., 1992. Tectonic evolution of the Japanese Islands as reflected in modal compositions of Cenozoic forearc and backarc sand and sandstone. Tectonics, 11(5):1028-1044. http:// dx.doi.org/10.1029/91TC03183

Milliken, K.L., 1988. Loss of provenance information through subsurface diagenesis in Plio-Pleistocene sandstones, northern Gulf of Mexico. Journal of Sedimentary
Research, 58(6):992-1002. http://dx.doi.org/10.1306/ 212F8EE0-2B24-11D7-8648000102C1865D

Milliken, K.L., Choh, S.-J., and McBride, E.F., 2007. Sandstone Petrology: A Tutorial Petrographic Image Atlas, (2nd edition) [CD-ROM]. AAPG/Datapages Discovery Series, 10. http://store.aapg.org/

Milliken, K.L., Comer, E.E., and Marsaglia, K.M., 2012. Data report: modal sand composition at Sites C0004, C0006, C0007, and C0008, IODP Expedition 316, Nankai accretionary prism. In Kinoshita, M., Tobin, H., Ashi, J., Kimura, G., Lallemant, S., Screaton, E.J., Curewitz, D., Masago, H., Moe, K.T., and the Expedition 314/315/316 Scientists, Proceedings of the Integrated Ocean Drilling Program, 314/315/316: Washington, DC (Integrated Ocean Drilling Program Management International, Inc.). http://dx.doi.org/10.2204/ iodp.proc.314315316.221.2012

Milliken, K.L., and Mack, L.E., 1990. Subsurface dissolution of heavy minerals, Frio Formation sandstones of the ancestral Rio Grande Province, South Texas. Sedimentary Geology, 68(3):187-199. http://dx.doi.org/ 10.1016/0037-0738(90)90111-6

Morton, A.C., 1984. Stability of detrital heavy minerals in Tertiary sandstones from the North Sea Basin. Clay Minerals, 19(3):287-308. http://dx.doi.org/10.1180/claymin.1984.019.3.04

Scholle, P.A., 1979. A color illustrated guide to constituents, textures, cements and porosities of sandstones and associated rocks. AAPG Memoir, 28.

Simpson, G.D.H., 2010. Formation of accretionary prisms influenced by sediment subduction and supplied by sediments from adjacent continents. Geology, 38(2):131-134. http://dx.doi.org/10.1130/G30461.1

Strasser, M., Dugan, B., Kanagawa, K., Moore, G.F., Toczko, S., Maeda, L., Kido, Y., Moe, K.T., Sanada, Y., Esteban, L., Fabbri, O., Geersen, J., Hammerschmidt, S., Hayashi, H., Heirman, K., Hüpers, A., Jurado Rodriguez, M.J., Kameo, K., Kanamatsu, T., Kitajima, H., Masuda, H., Milliken, K., Mishra, R., Motoyama, I., Olcott, K., Oohashi, K., Pickering, K.T., Ramirez, S.G., Rashid, H., Sawyer, D., Schleicher, A., Shan, Y., Skarbek, R., Song, I., Takeshita, T., Toki, T., Tudge, J., Webb, S., Wilson, D.J., Wu, H.-Y., and Yamaguchi, A., 2014. Site C0002. In Strasser, M., Dugan, B., Kanagawa, K., Moore, G.F., Toczko, S., Maeda, L., and the Expedition 338 Scientists, Proceedings of the Integrated Ocean Drilling Program, 338: Yokohama (Integrated Ocean Drilling Program). http:// dx.doi.org/10.2204/iodp.proc.338.103.2014

Taira, A., and Niitsuma, N., 1986. Turbidite sedimentation in the Nankai Trough as interpreted from magnetic fabric, grain size, and detrital modal analyses. In Kagami, H., Karig, D.E., Coulbourn, W.T., et al., Initial Reports of the Deep Sea Drilling Project, 87: Washington, DC (U.S. Govt. Printing Office), 611-632. http://dx.doi.org/ 10.2973/dsdp.proc.87.112.1986

Underwood, M.B., and Fergusson, C.L., 2005. Late Cenozoic evolution of the Nankai trench-slope system: Evidence from sand petrography and clay mineralogy. In Hodgson, D., and Flint, S. (Eds.), Submarine Slope Sys- 
tems: Processes, Products and Prediction. Geological Society Special Publication, 244(1):113-129. http:// dx.doi.org/10.1144/GSL.SP.2005.244.01.07

Usman, M.O., Masago, H., Winkler, W., and Strasser, M., 2014. Mid-Quaternary decoupling of sediment routing in the Nankai forearc revealed by provenance analysis of turbiditic sands. International Journal of Earth Sciences, 103(4):1141-1161. http://dx.doi.org/10.1007/s00531014-1011-Z

Initial receipt: 14 September 2015

Acceptance: 30 November 2015

Publication: 16 February 2016

MS 338-204 
Figure F1. Sedimentary rock fragments: clay-rich mudstones. Grains rich in clay-size clay minerals with minor admixtures of possible organic matter and opaque crystals such as pyrite. Left $=$ plane-polarized light, right $=$ cross-polarized light.
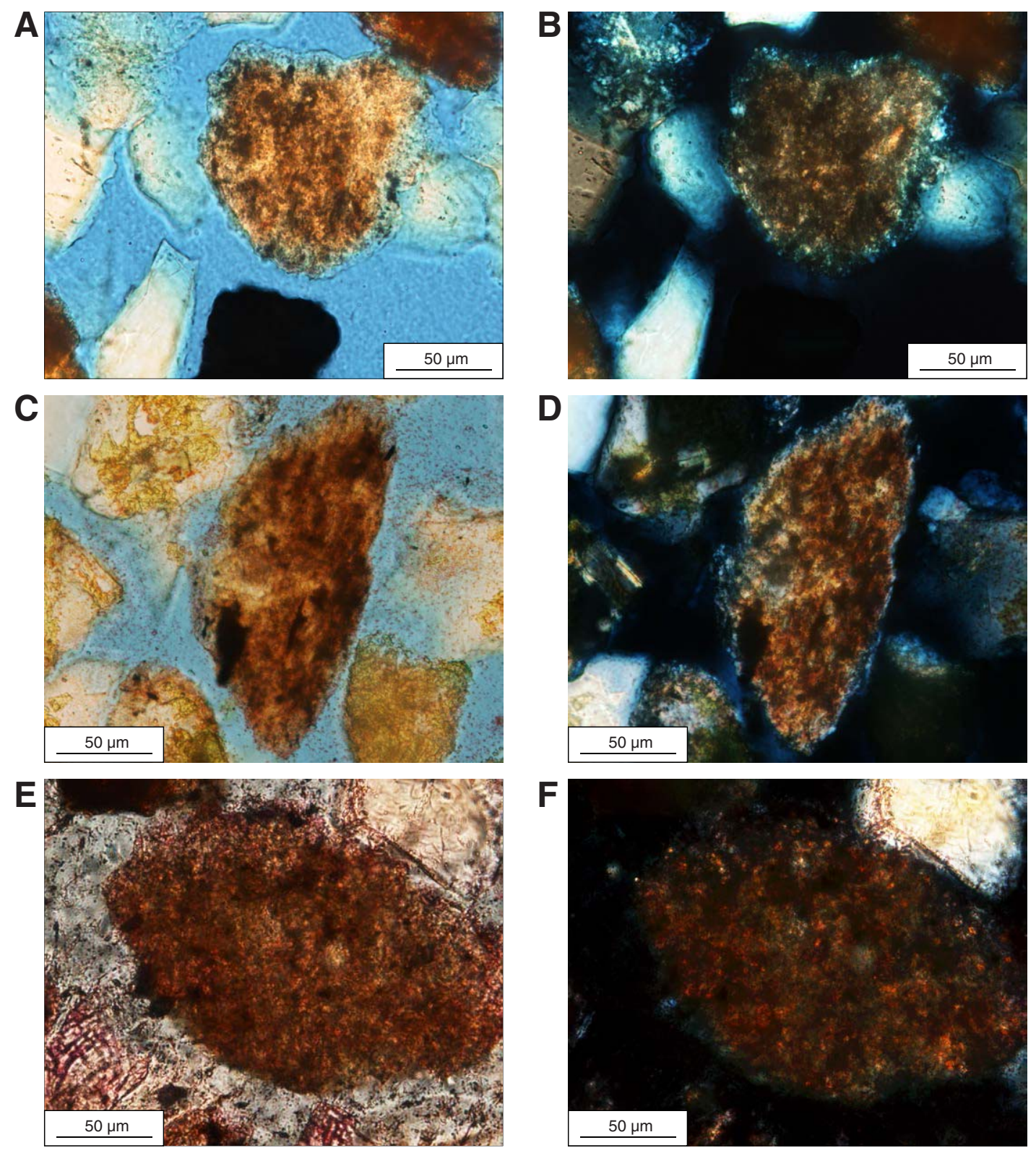
Figure F2. Sedimentary rock fragments: clay-rich mudstones. Grains rich in clay-size clay minerals with minor admixtures of possible organic matter and opaque crystals such as pyrite. Bottom grain (E, F) contains a moderate amount of clay-size carbonate. Left $=$ plane-polarized light, right $=$ cross-polarized light.
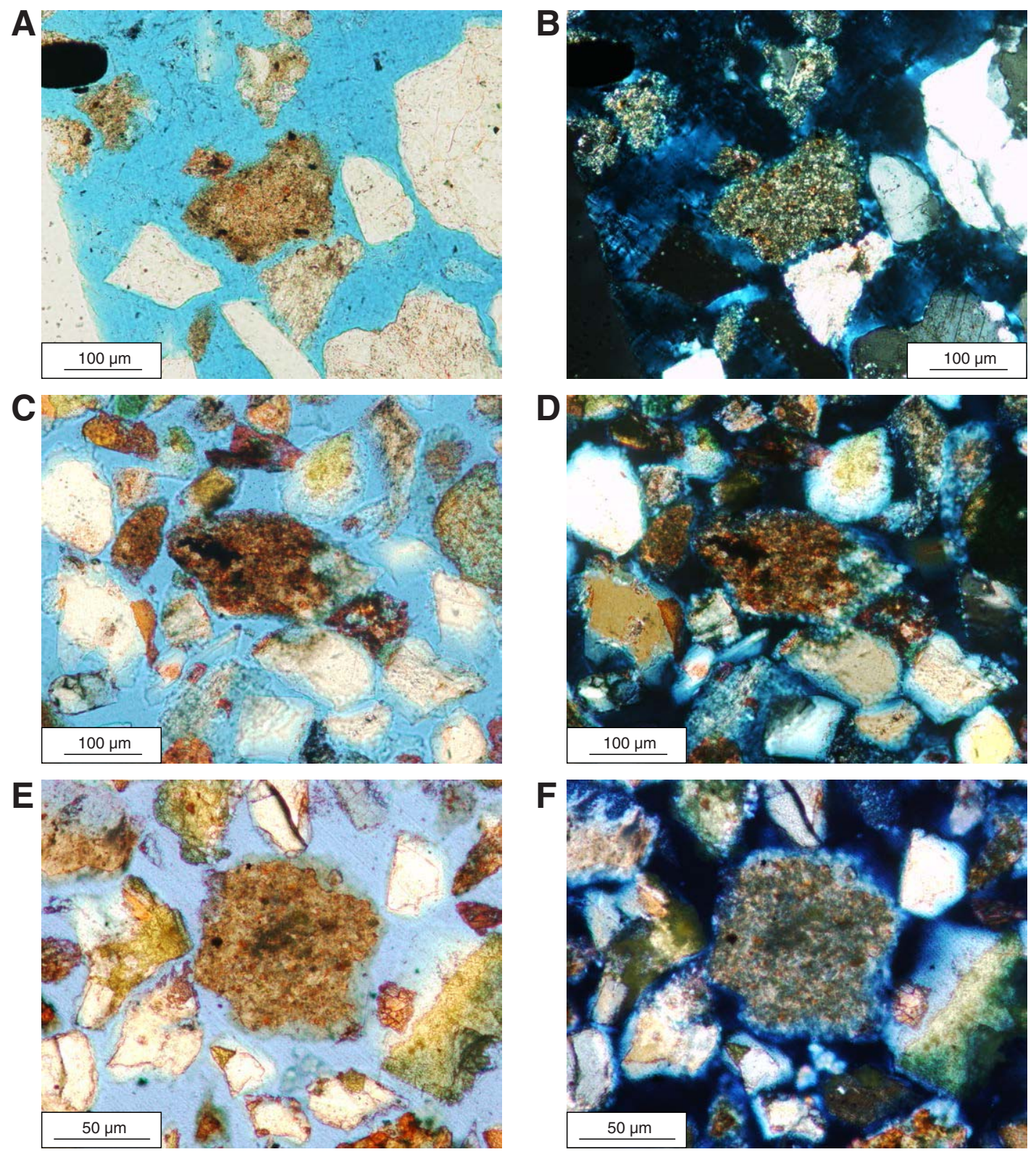
Figure F3. Sedimentary rock fragments: clay-rich mudstones. Color zoning in these samples is likely the result of varying degrees of epoxy penetration during the thin section making process. This interpretation is based upon the similarity to variable epoxy impregnation commonly observed in whole-rock mudstone thin sections. Left $=$ plane-polarized light, right $=$ cross-polarized light.
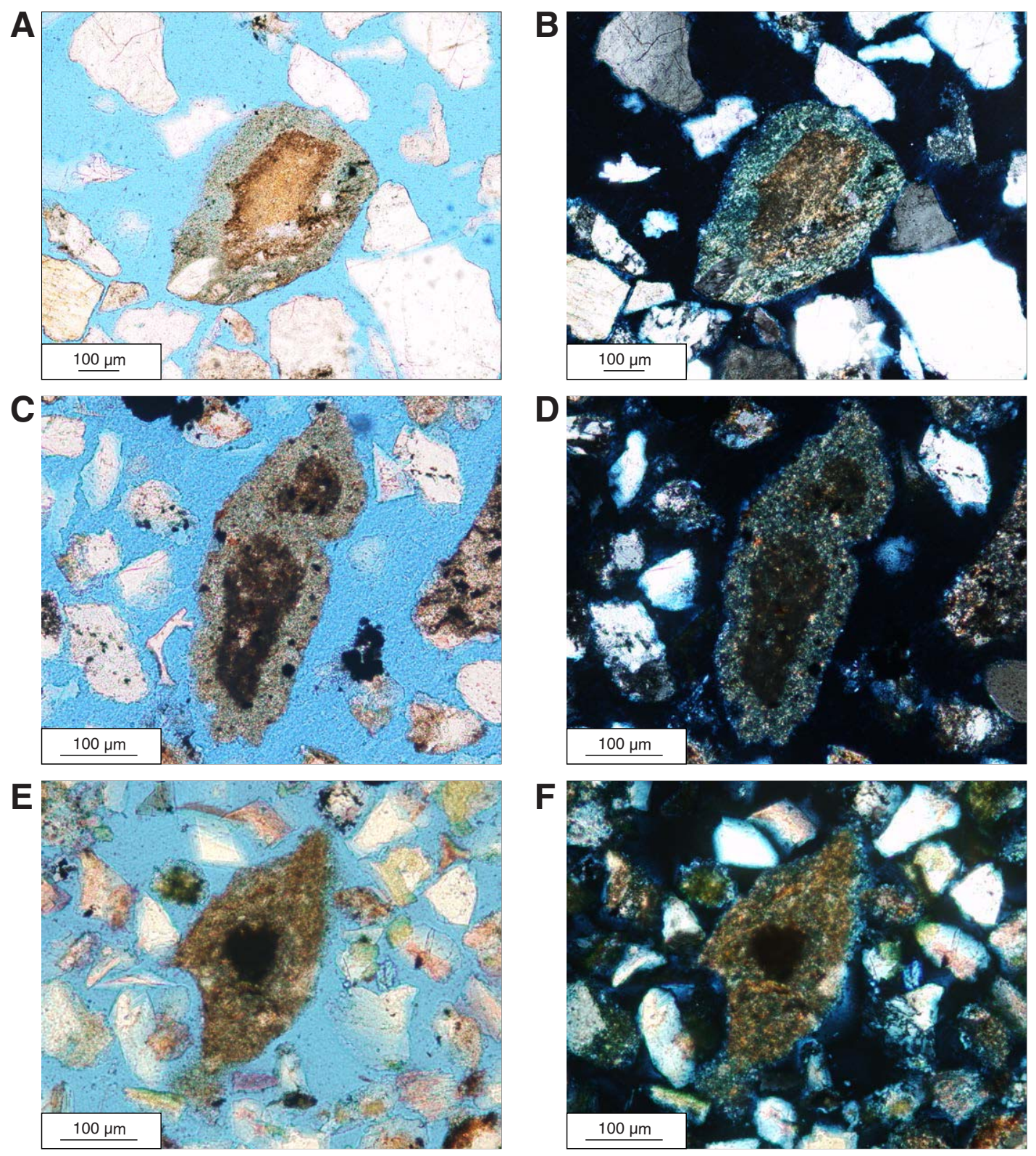
Figure F4. Sedimentary rock fragments: clay-rich mudstones. A, B. Grain has fractures filled with microcrystalline quartz (chert). C, D. Near-opaque grain has fracture filled with chlorite. Grain in lower right has a chertfilled fracture. E, F. Clay-rich mudstone grain containing a sand-size quartz clast. Left = plane-polarized light, right $=$ cross-polarized light.
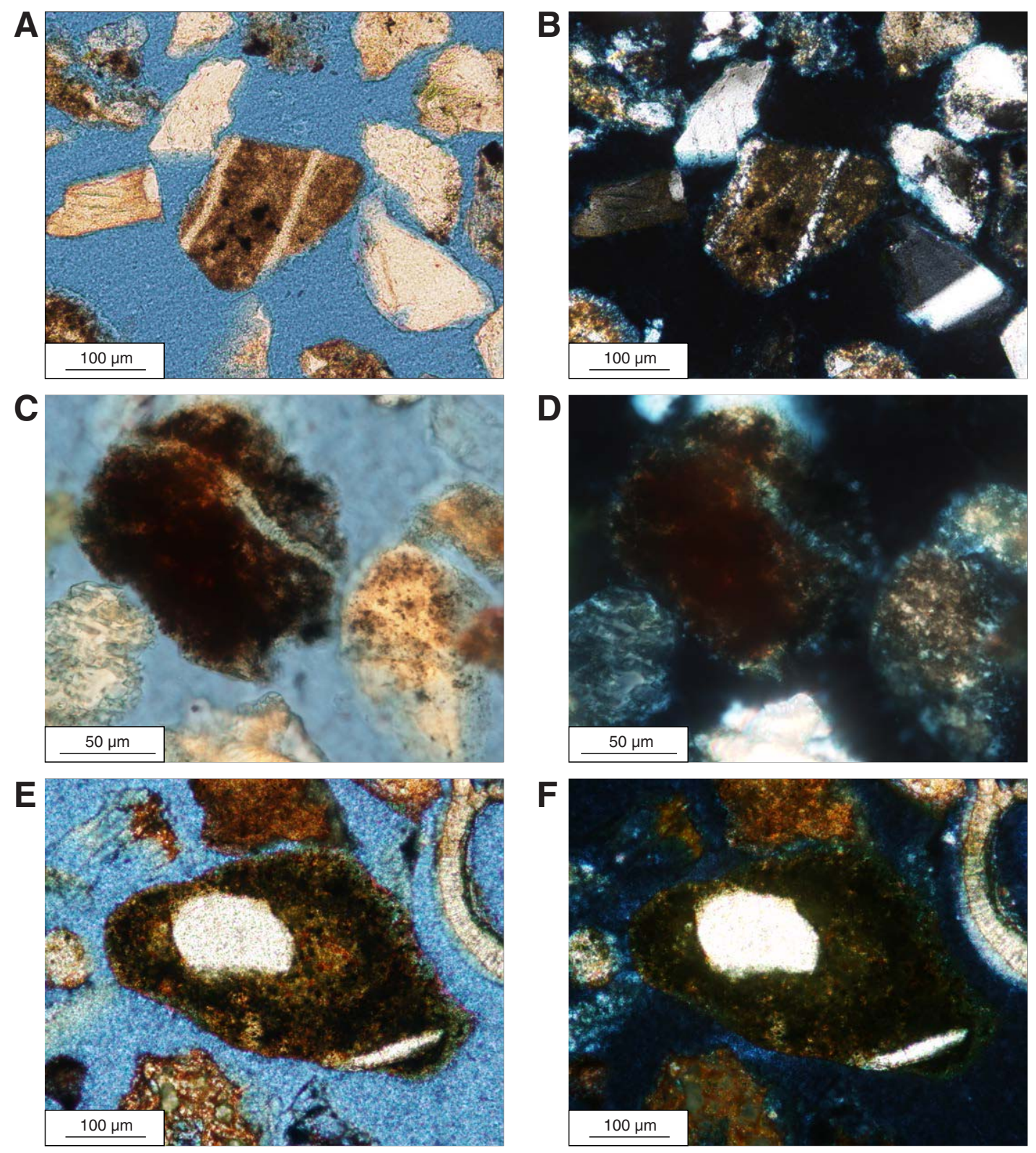
Figure F5. Sedimentary rock fragments: clay-rich mudstones. Silt-size particles are quartz and feldspar. Mudstones are silt bearing. Left $=$ plane-polarized light, right $=$ cross-polarized light .
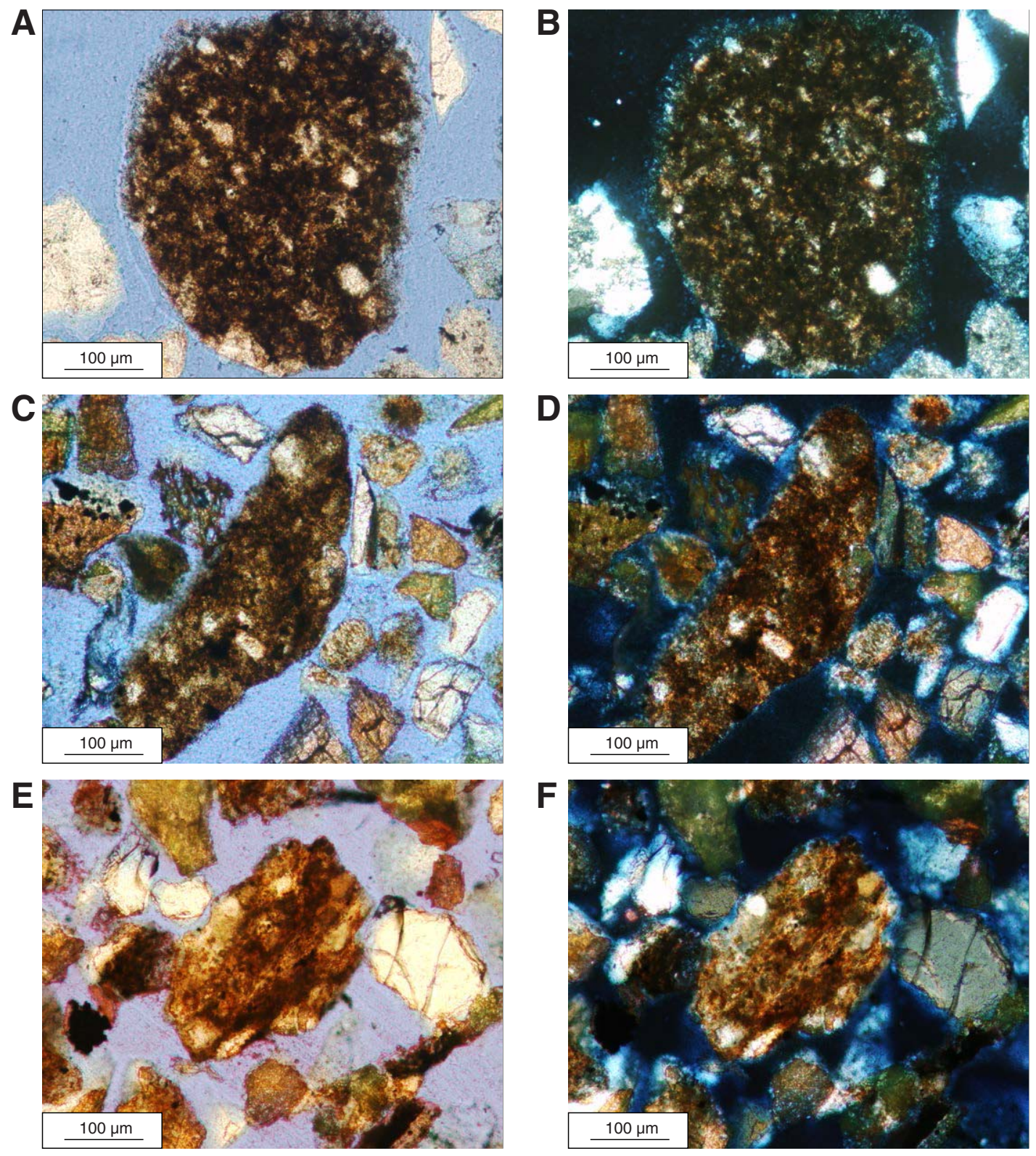
Figure F6. Sedimentary rock fragments: silt-rich mudstones. Silt-size particles are quartz and feldspar. Left = plane-polarized light, right $=$ cross-polarized light.
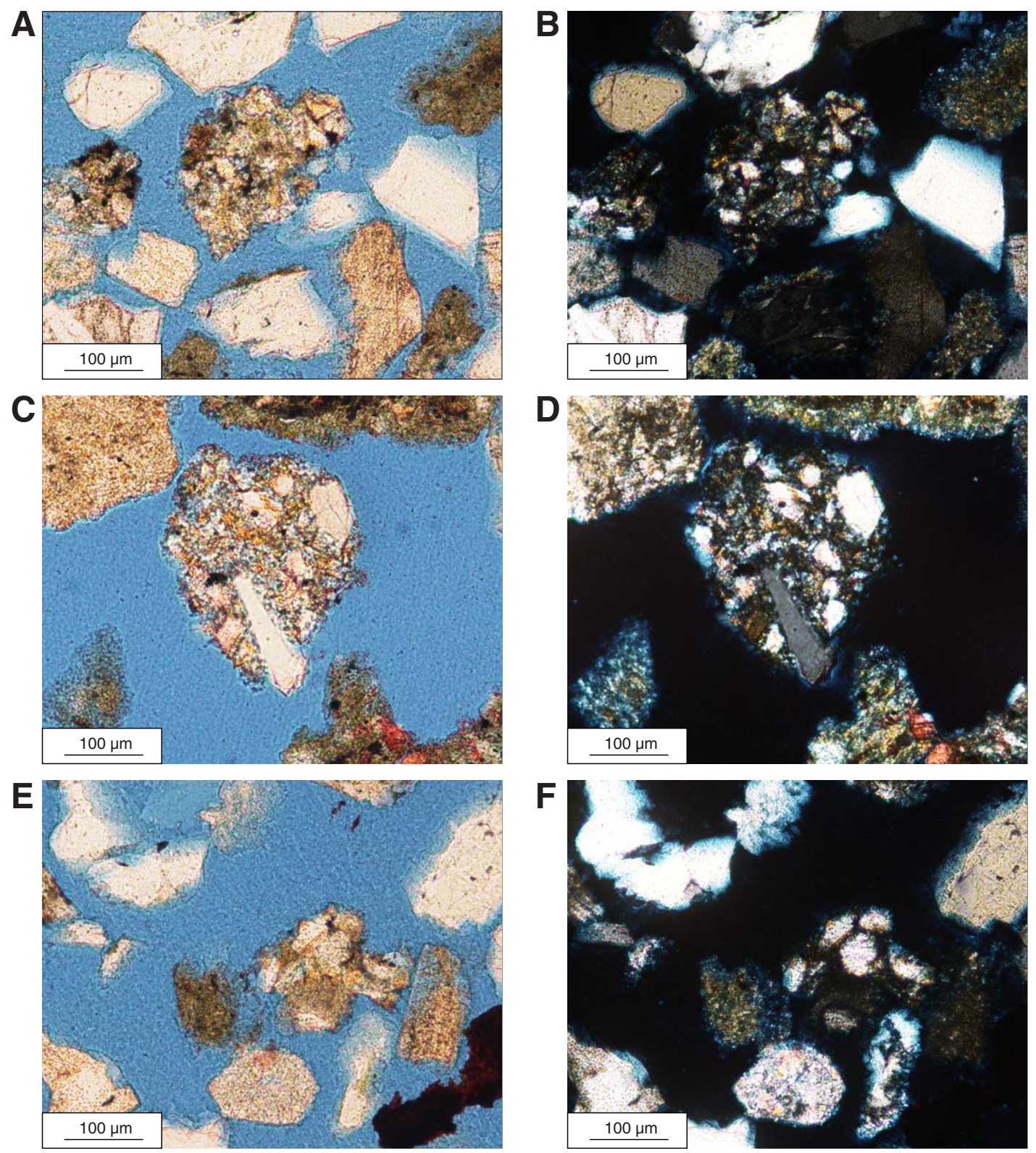
Figure F7. Sedimentary rock fragments: silt-rich mudstones. A-D. Mudstones (silt-rich). E, F. Muddy sandstone. Large sand-size grain; on right side is a metamorphic rock fragment composed of quartz, feldspar and chlorite. Smaller grains include quartz and feldspar. Left = plane-polarized light, right = cross-polarized light .
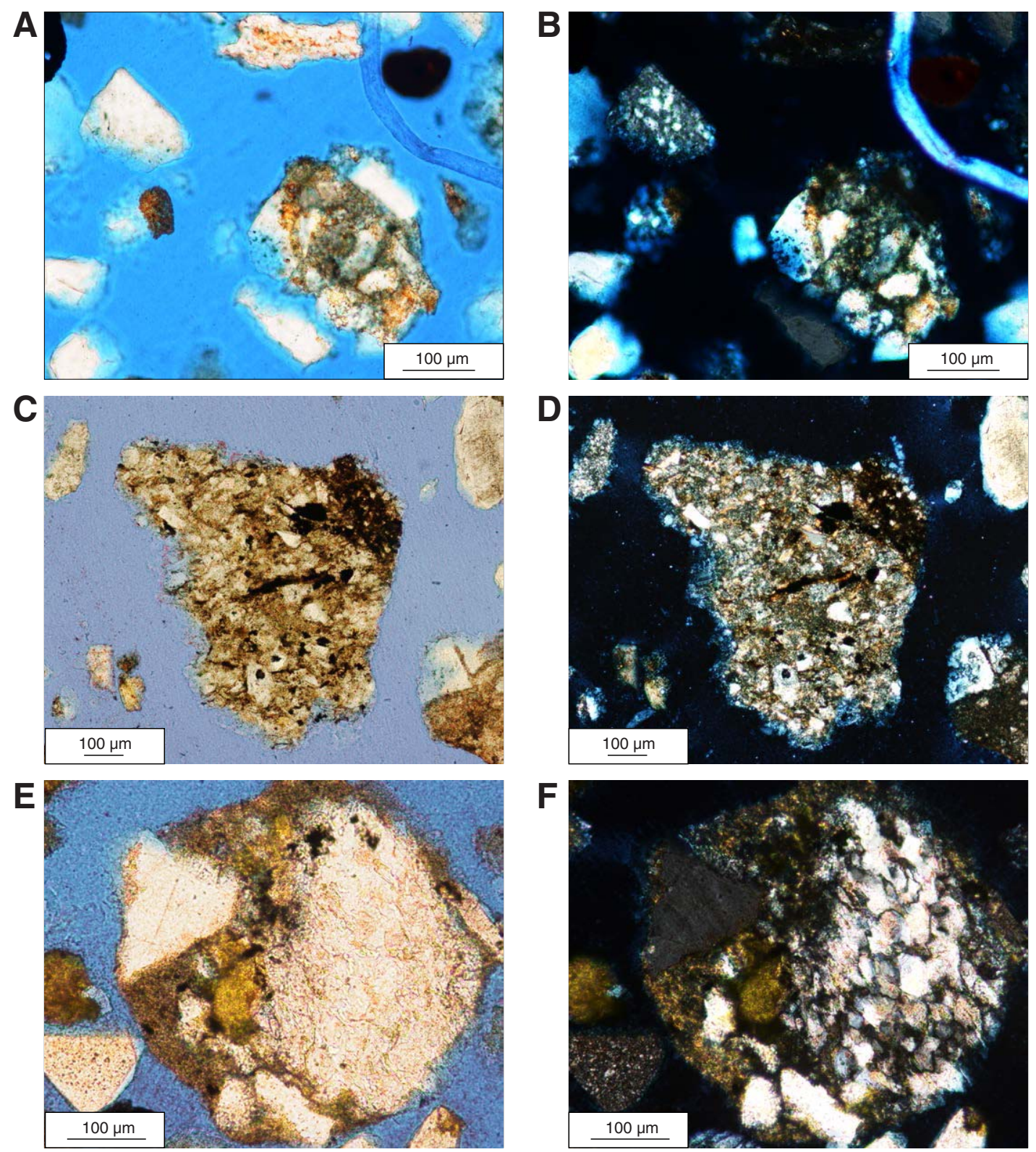
Figure F8. Sedimentary rock fragments: argillaceous cherts. A, B. Opaque crystals are probably pyrite. Left = plane-polarized light, right $=$ cross-polarized light.
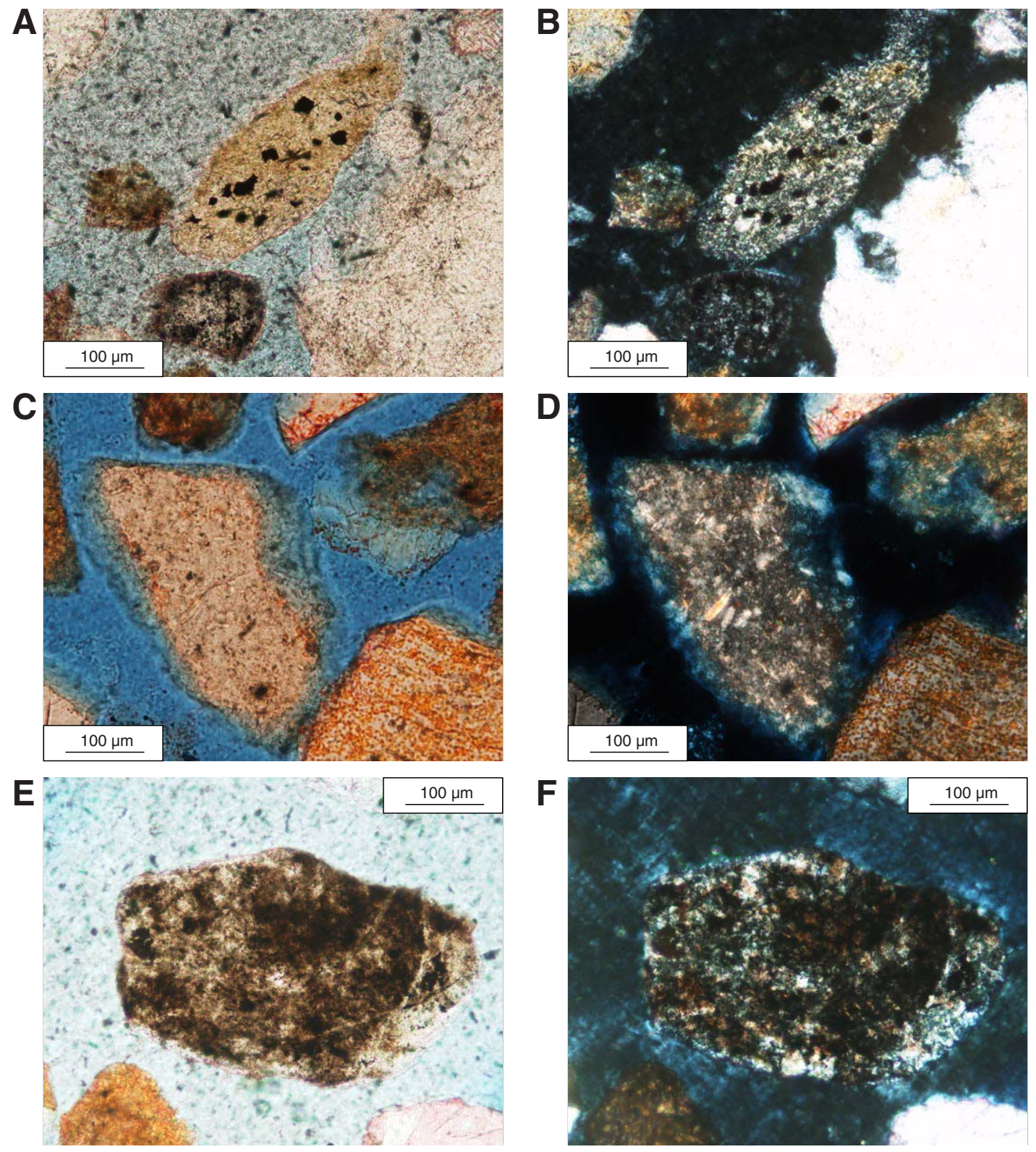
Figure F9. Sedimentary rock fragments: cherts and other microcrystalline quartz. A, B. Fine grained. C, D. Wellrounded grain, potentially formed within a vesicle of a volcanic rock fragment (Fig. F15E-F15F). While not strictly sedimentary, this grain is interpreted to have formed through water-rock interaction similar in nature to diagenesis. E, F. Oversized grain with fractures filled with microcrystalline quartz. Left = plane-polarized light, right $=$ cross-polarized light.
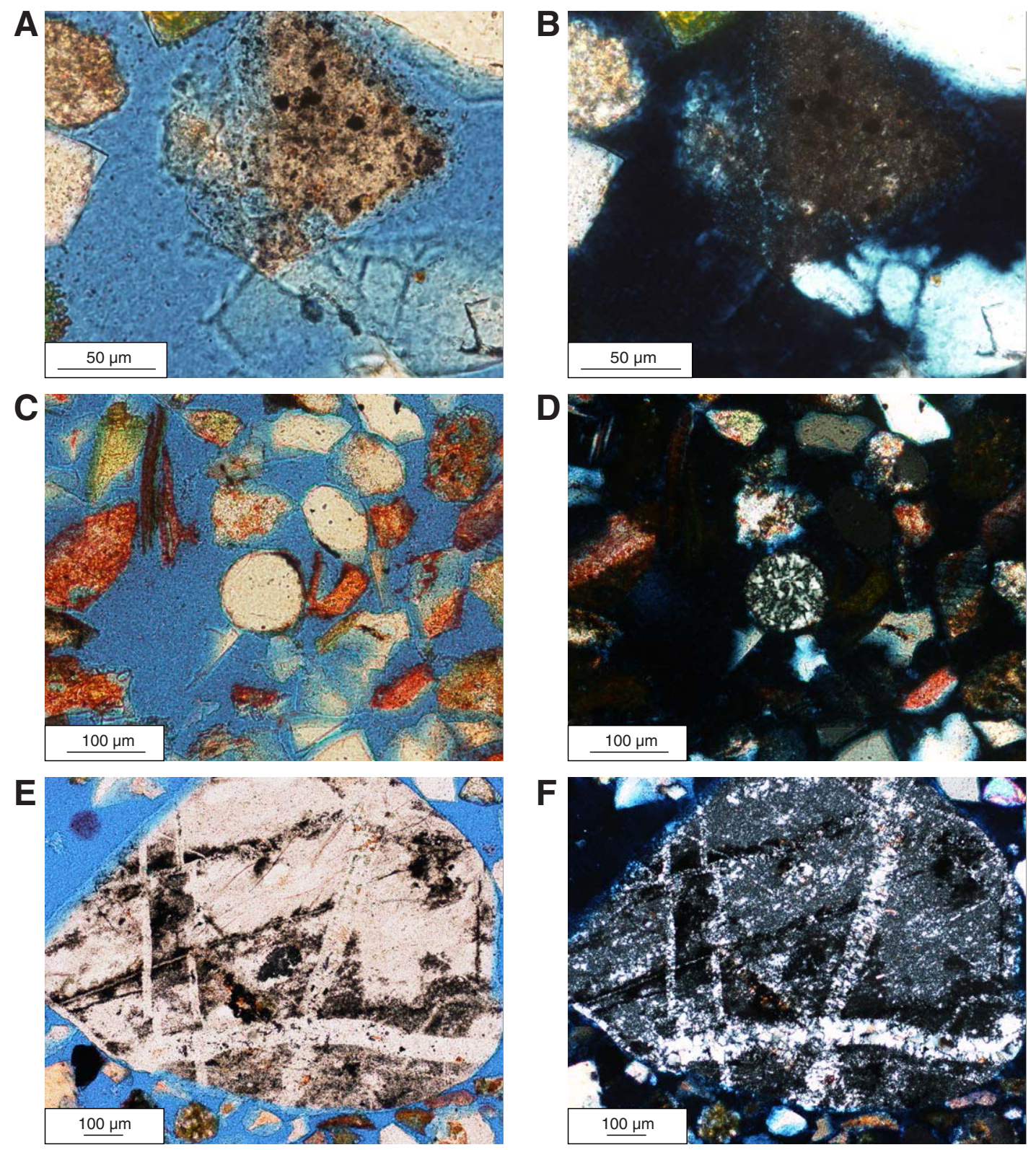
Figure F10. Volcanic rock fragments: felsitic grains are characterized by microcrystalline quartz and feldspar crystals of equant dimensions. The presence of abundant feldspar is denoted by the prominent yellow stain. These grains also contain a substantial admixture of clay-size clay minerals and various opaque crystals. Left = plane-polarized light, right $=$ cross-polarized light.
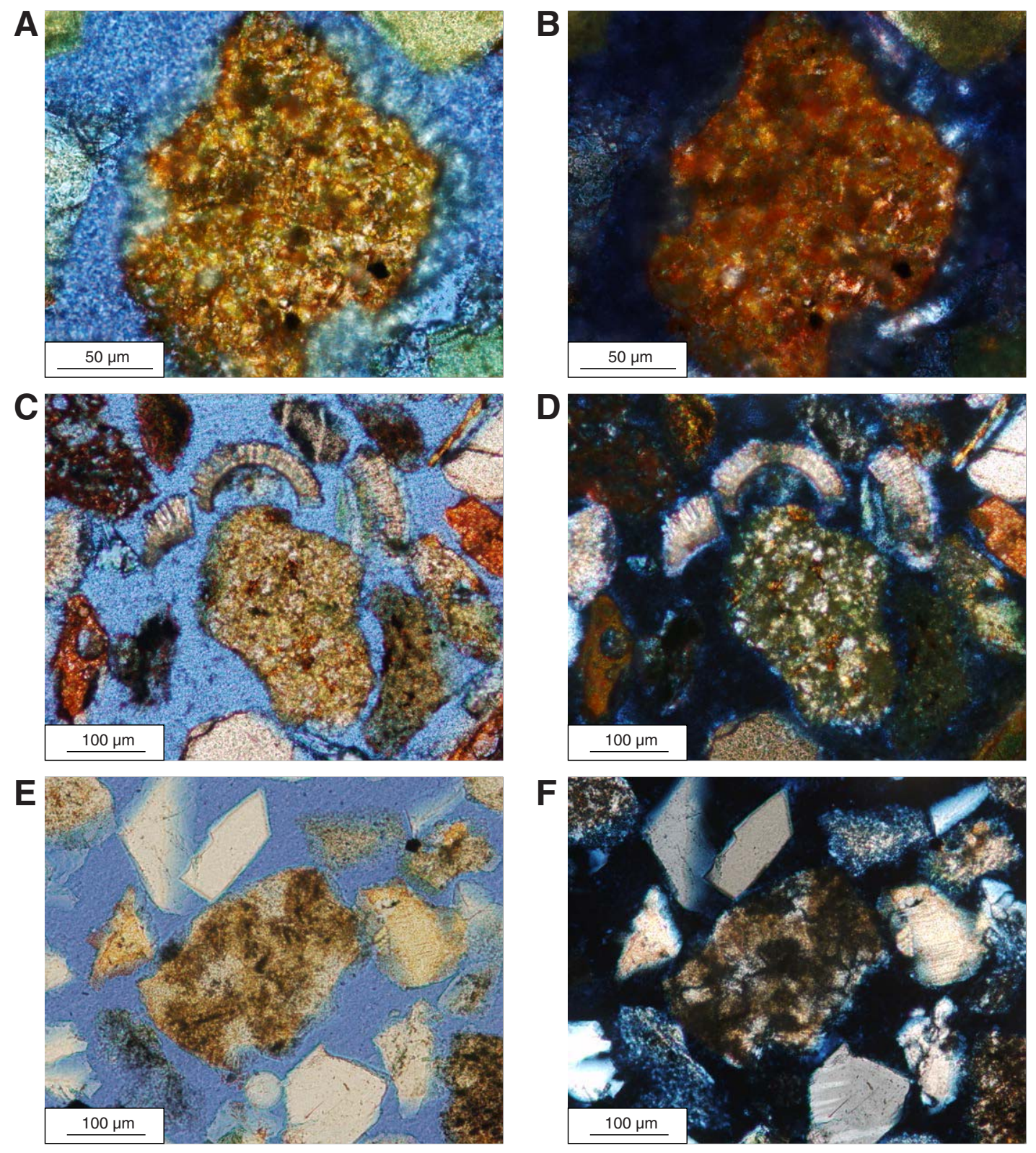
Figure F11. Volcanic rock fragments: felsitic grains are characterized by microcrystalline quartz and feldspar crystals of equant dimensions. The presence of abundant feldspar is denoted by the prominent yellow stain. These grains also contain a substantial admixture of clay-size clay minerals and various opaque crystals. Left = plane-polarized light, right $=$ cross-polarized light.
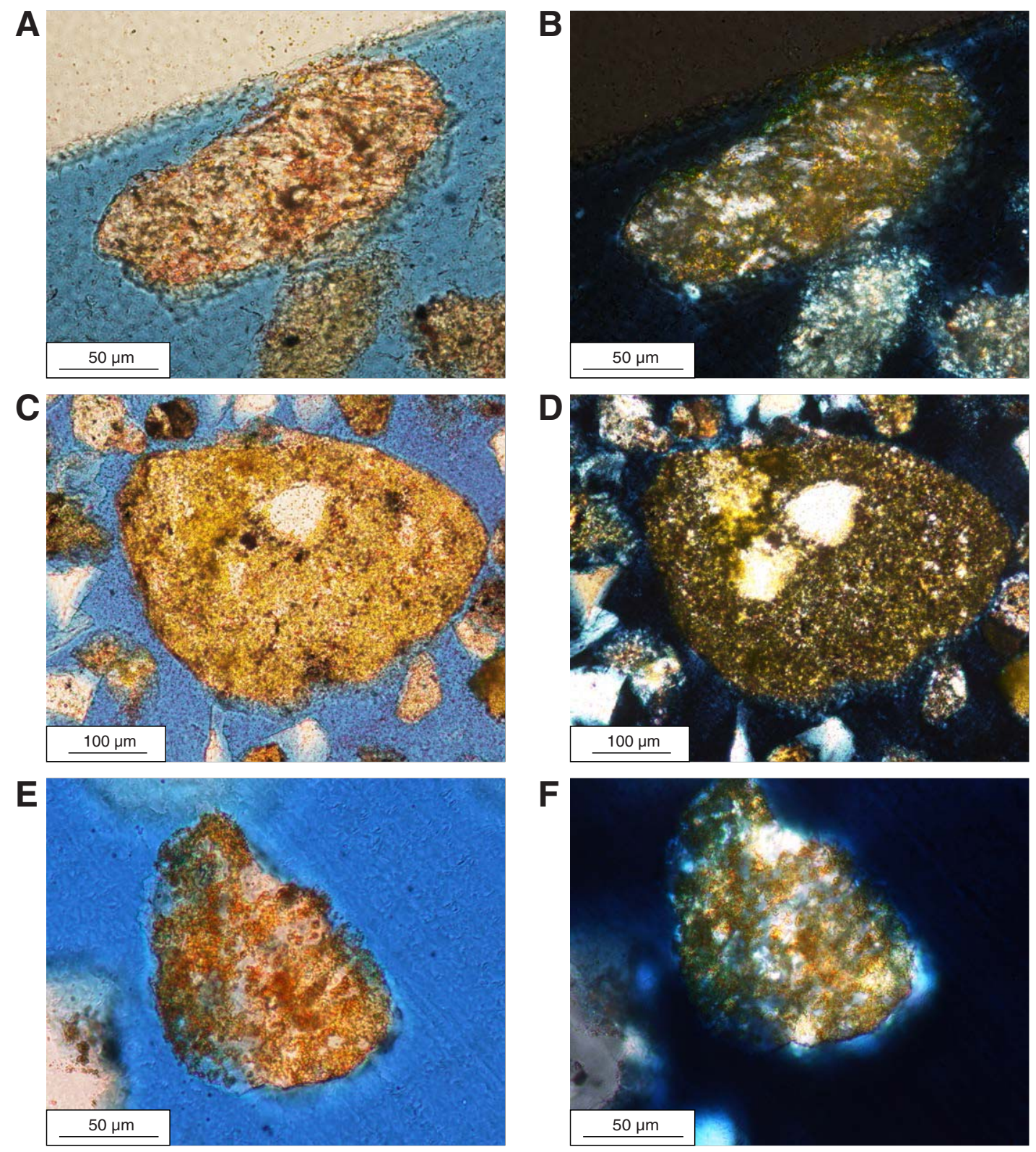
Figure F12. Volcanic rock fragments: microlitic grains containing distinct microcrystals of feldspars floating in a finer grained groundmass of variable feldspar and quartz content. A, B. Note the unstained microliths, probable albitic plagioclase . Left $=$ plane-polarized light, right $=$ cross-polarized light .
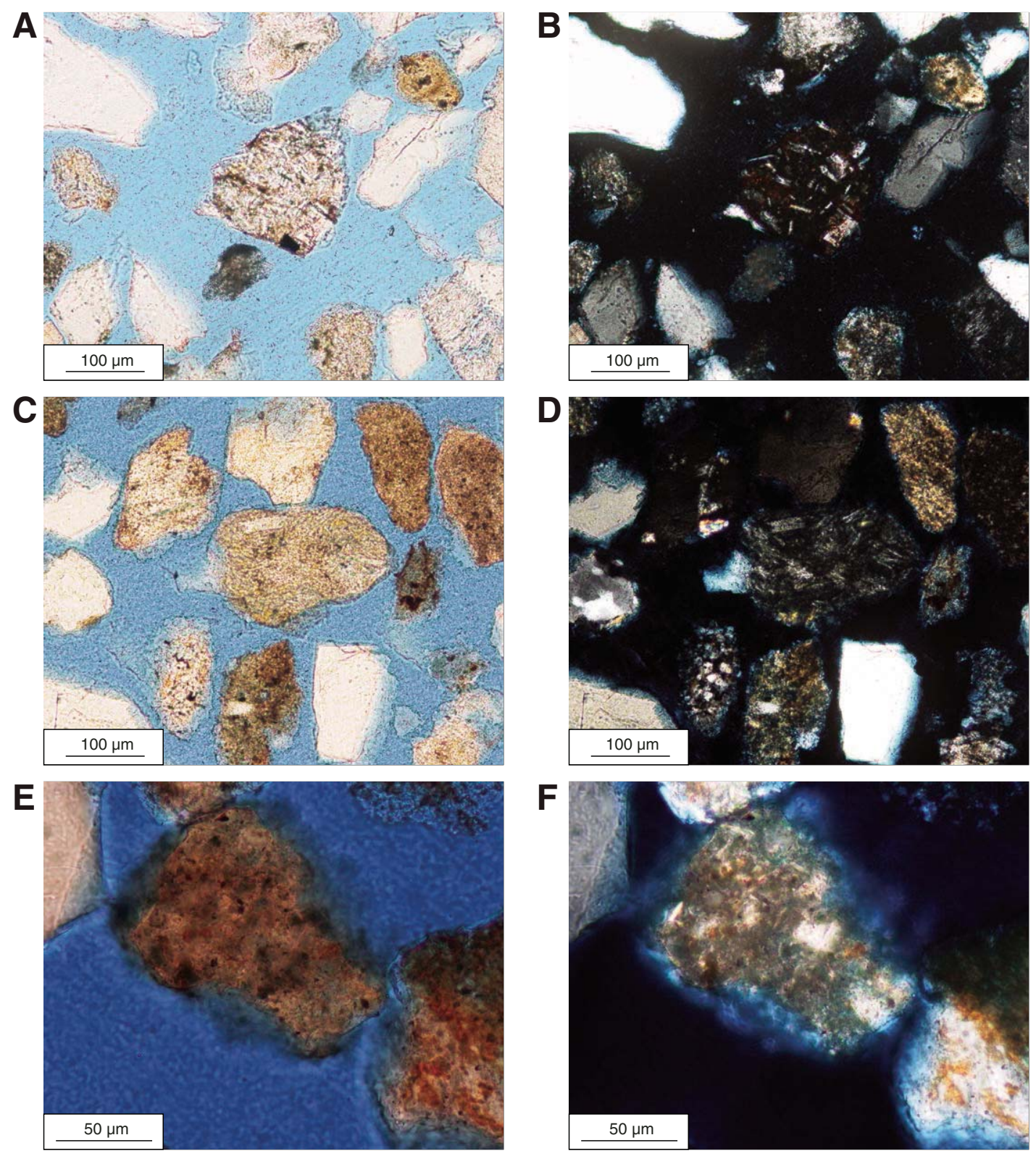
Figure F13. Volcanic rock fragments: lathwork. A, B, E, F. Highly altered grains. C, D. Note the unstained microliths, probable albitic plagioclase . Left $=$ plane-polarized light, right $=$ cross-polarized light .
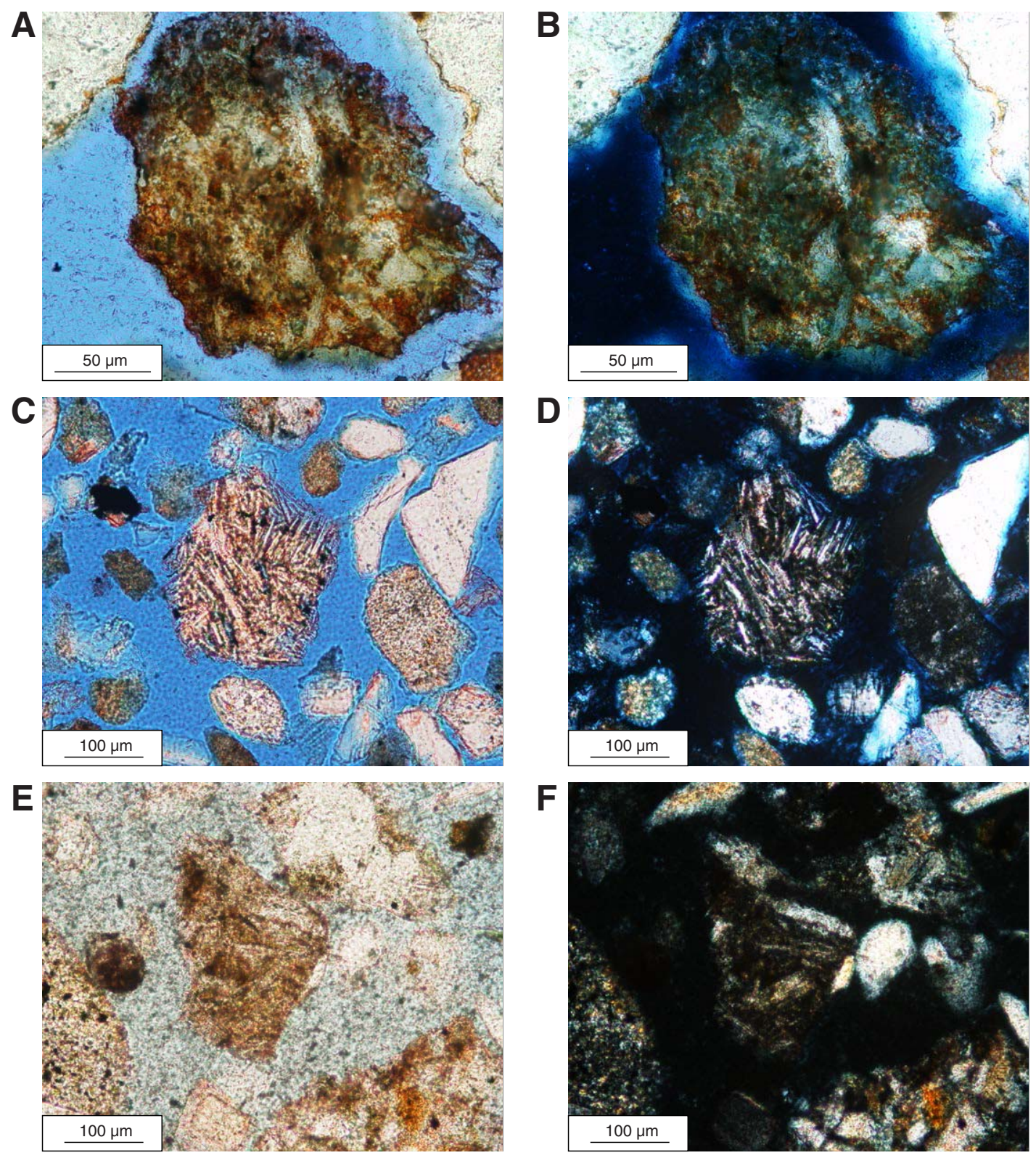
Figure F14. Volcanic rock fragments: trachytic lathwork. Lath crystals are plagioclase. E, F. Note dual K-feldspar and plagioclase staining in the groundmass. Left $=$ plane-polarized light, right $=$ cross-polarized light
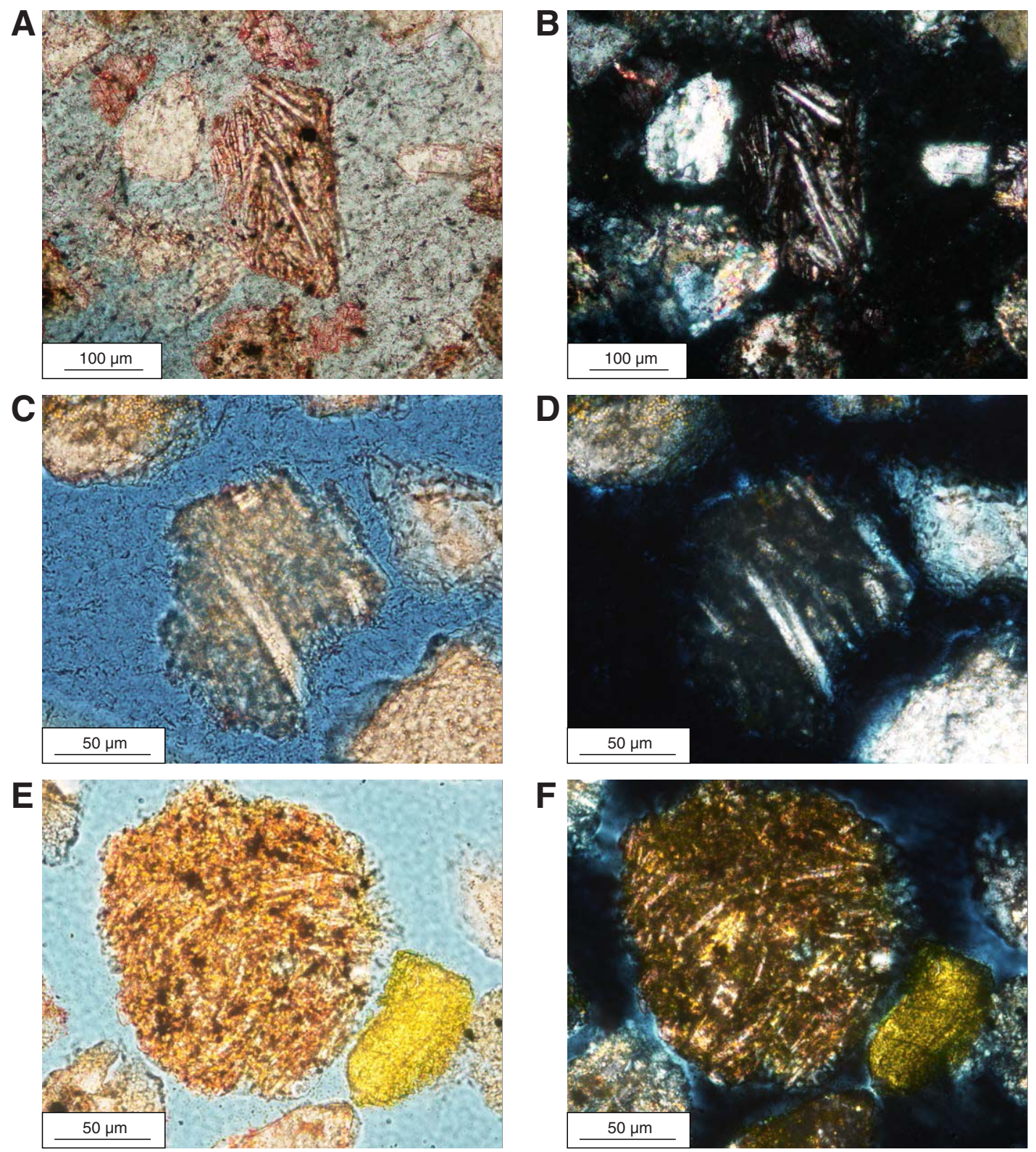
Figure F15. Volcanic rock fragments: pumice, increasing degree of devitrification. Note the microcrystalline quartz-filled vesicle in $\mathbf{E}$ and $\mathbf{F}$. Left = plane-polarized light, right = cross-polarized light.
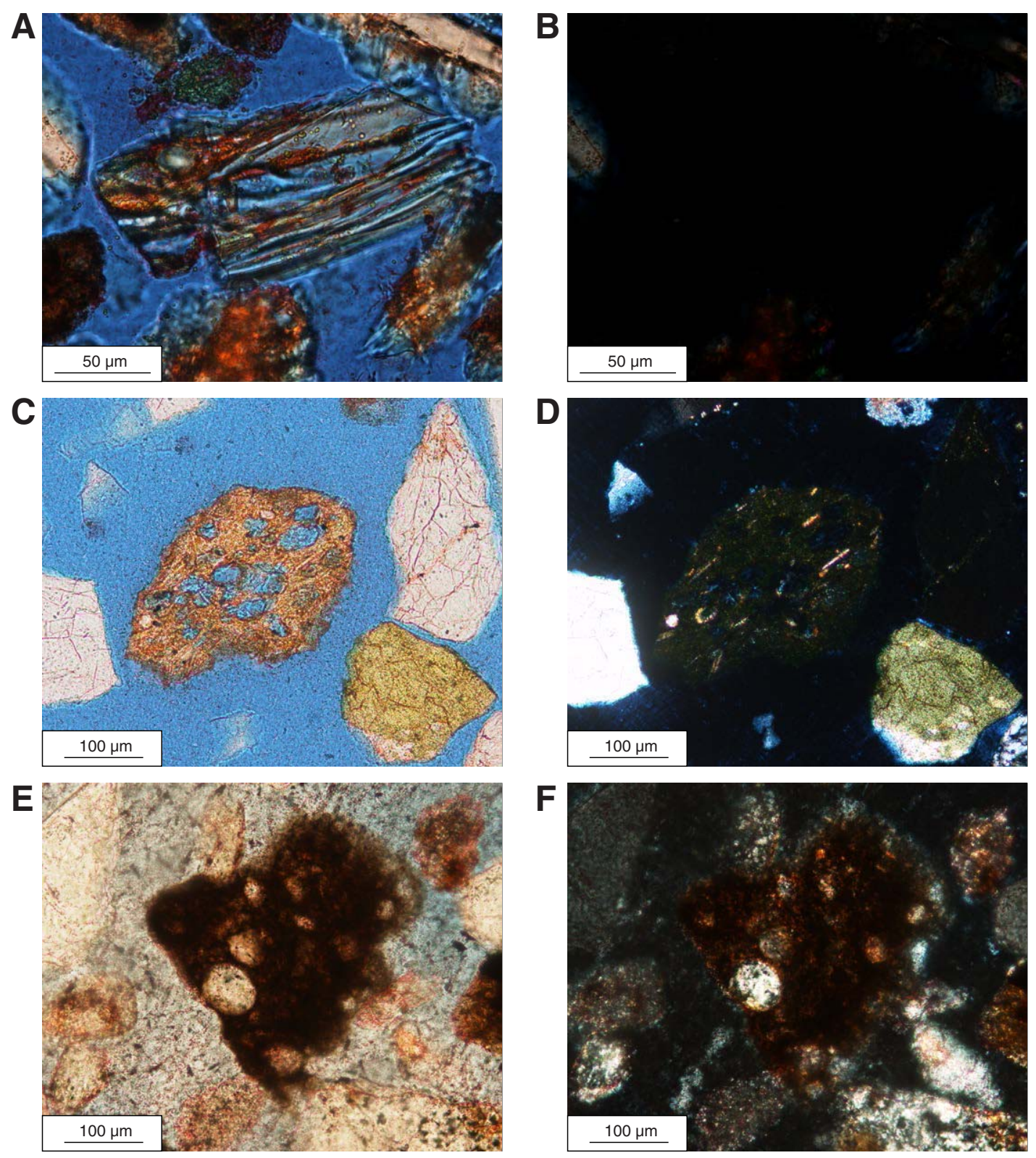
Figure F16. Plutonic rock fragments: quartz-plagioclase-k-feldspar aggregates. Feldspars denoted by staining. Left $=$ plane-polarized light, right $=$ cross-polarized light .
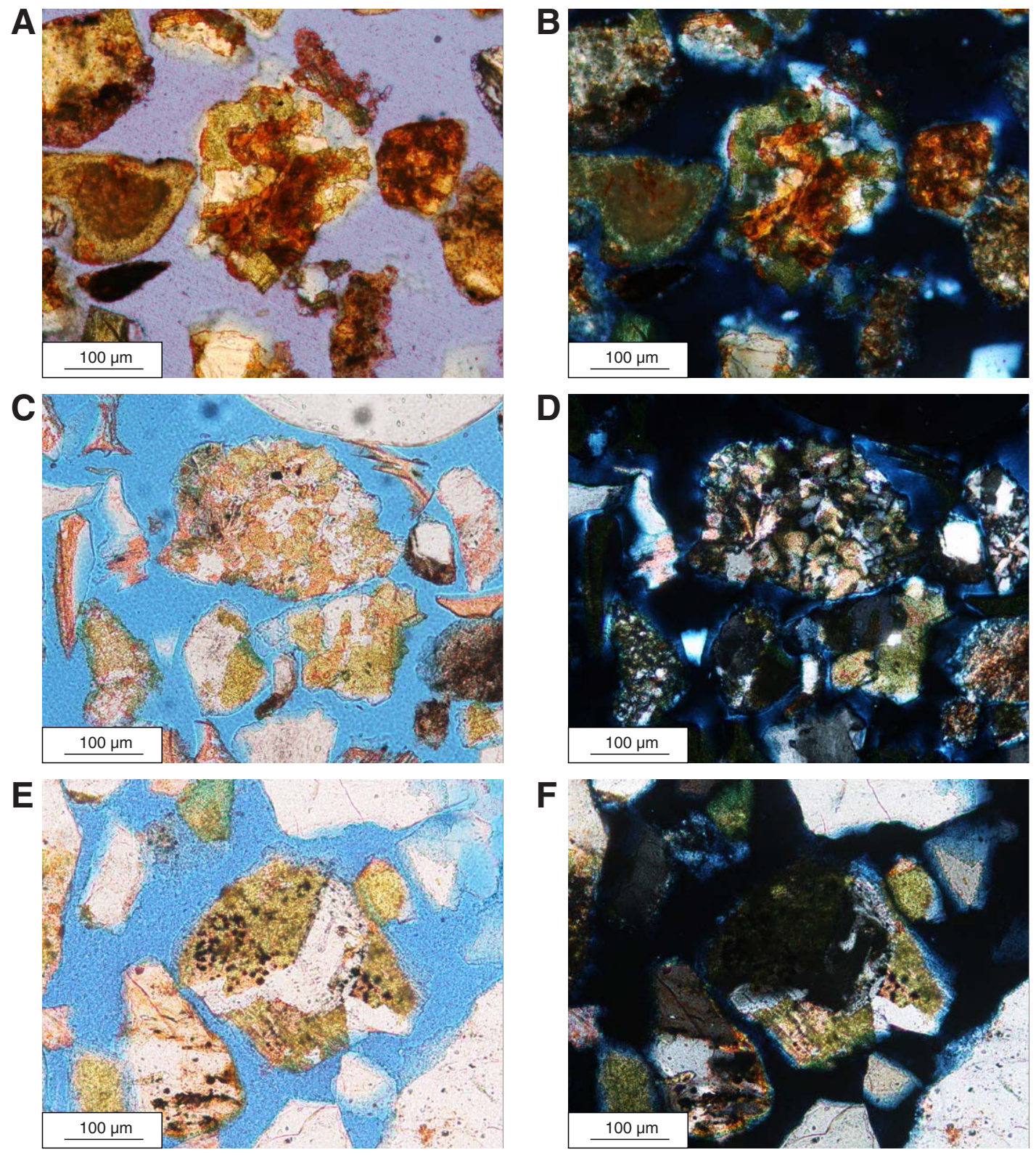
Figure F17. Plutonic rock fragments. C, D, E, F. Note carbonate alteration on feldspars. For C and D, alternative interpretation would be carbonate-altered sandstone clast, however, sedimentary fabrics are not clear. Left = plane-polarized light, right $=$ cross-polarized light.
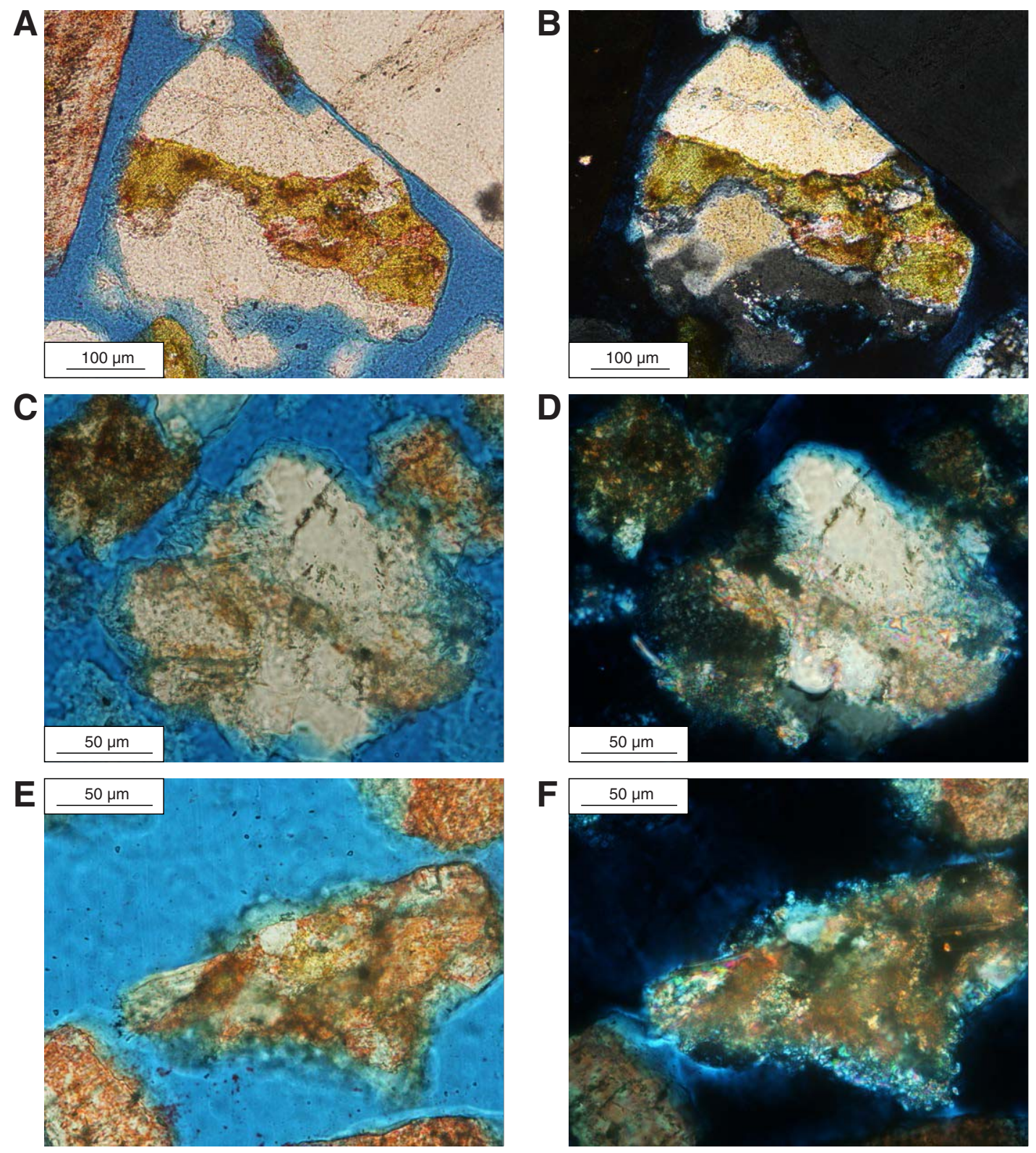
Figure F18. Plutonic rock fragments: quartz-K-feldspar intergrowths. Left $=$ plane-polarized light, right $=$ crosspolarized light.
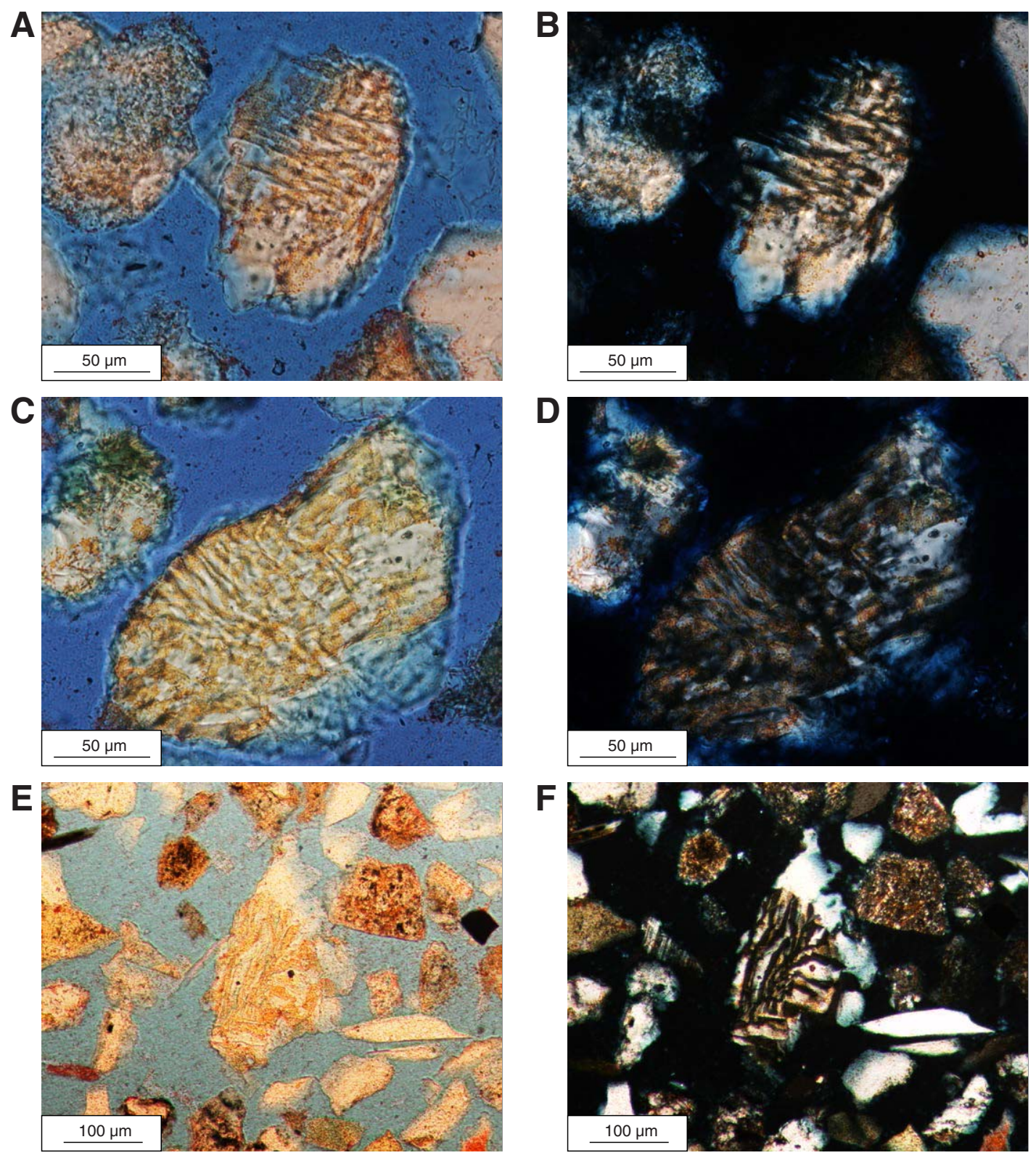
Figure F19. Plutonic rock fragments. A, B. Quartz-muscovite aggregate. C, D. Quartz-plagioclase aggregate. E, F. Quartz-epidote-plagioclase (albite) aggregate. Left $=$ plane-polarized light, right $=$ cross-polarized light.
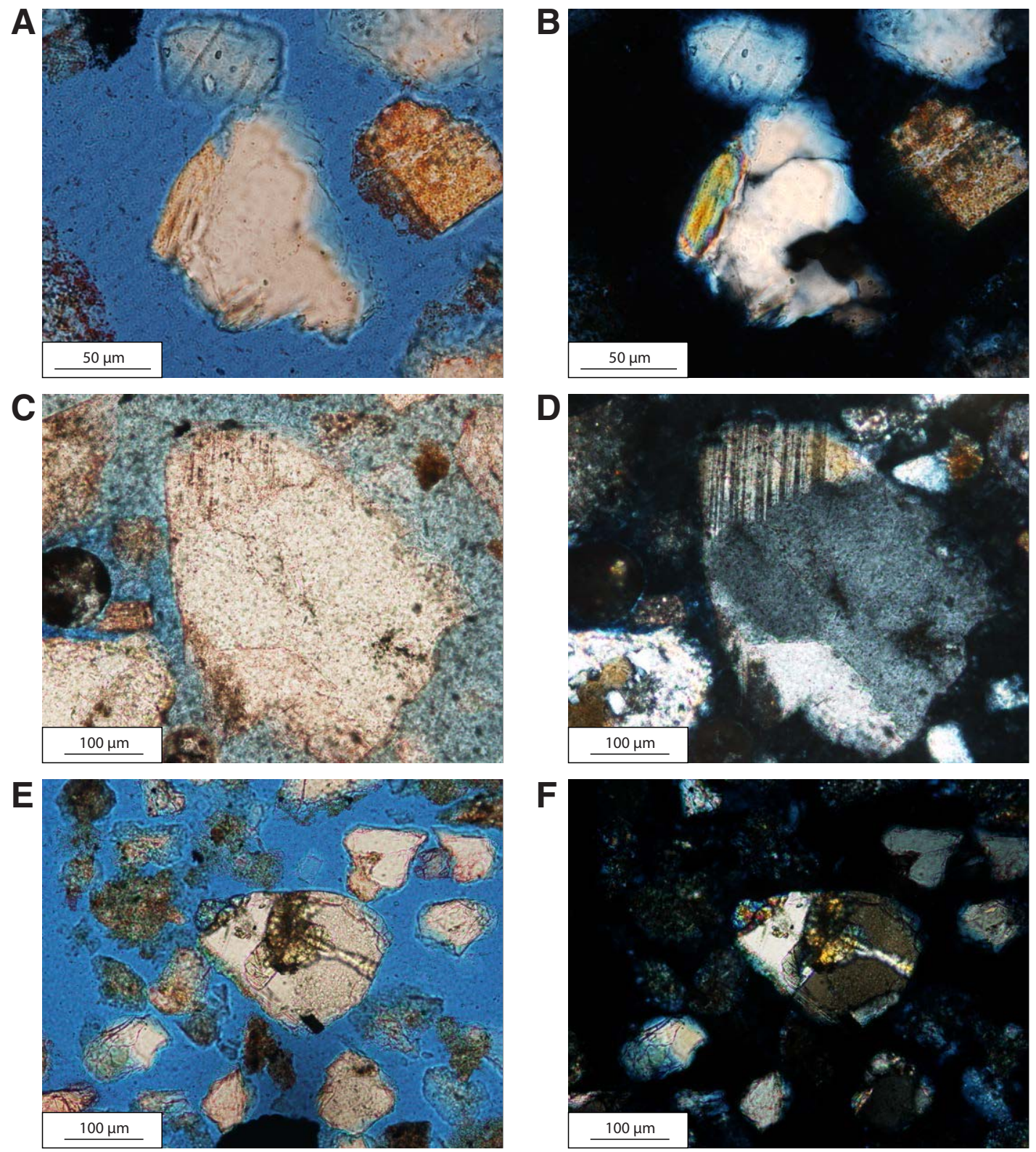
Figure F20. Metamorphic rock fragments: quartz-rich, foliated. Left = plane-polarized light, right = cross-polarized light.
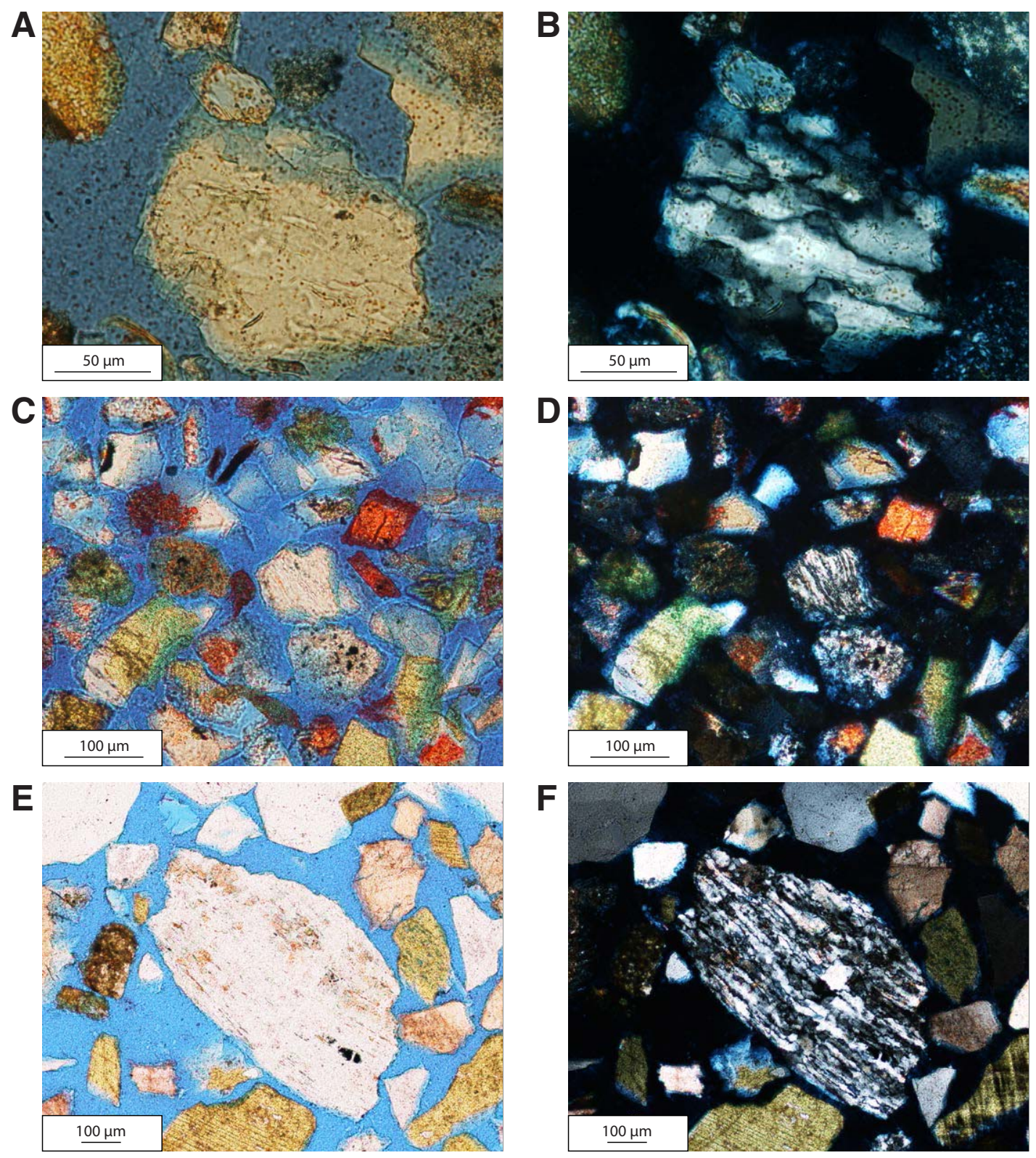
Figure F21. Metamorphic rock fragments: quartz-mica rich, foliated. Left = plane-polarized light, right $=$ crosspolarized light.
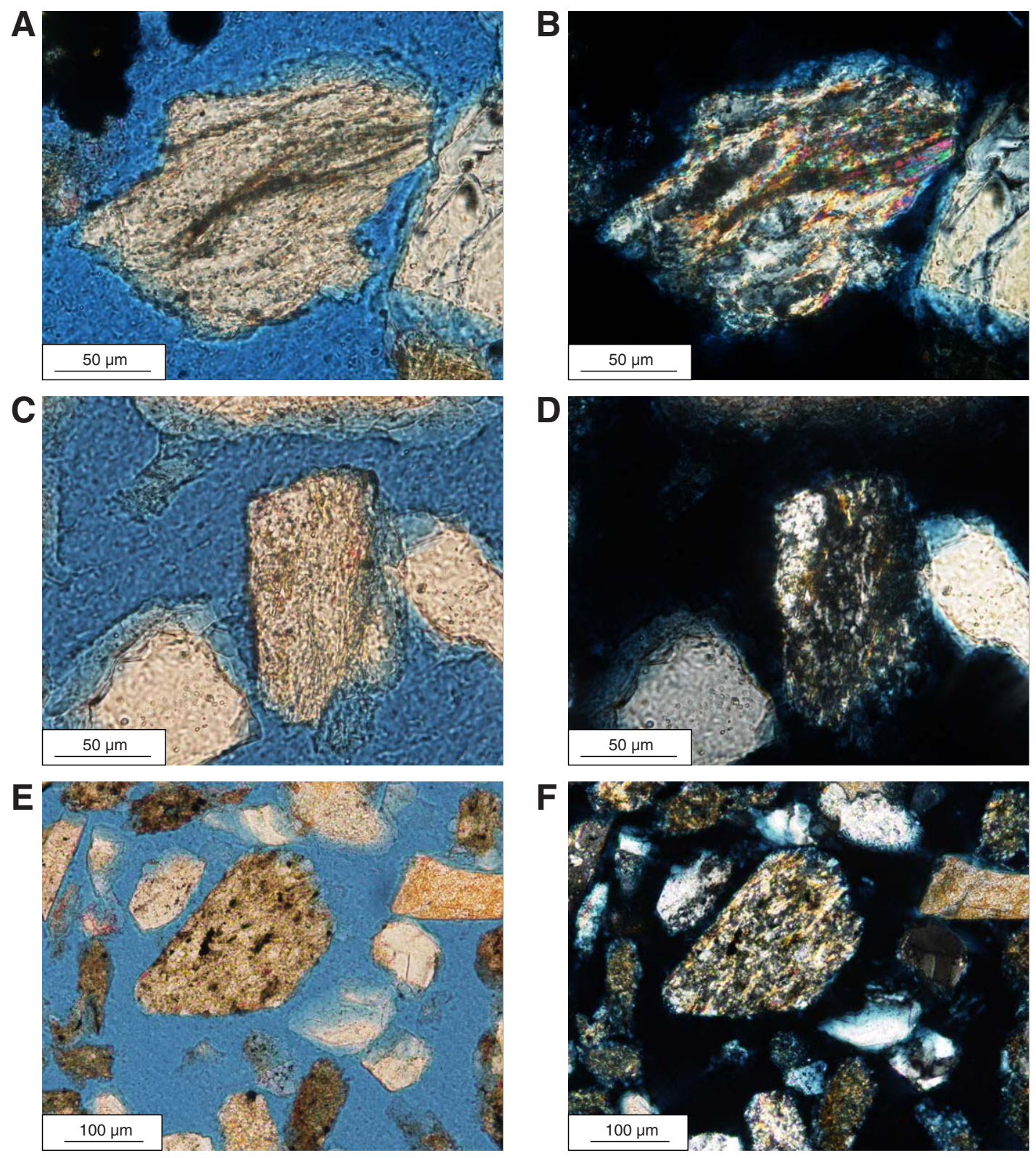
Figure F22. Metamorphic rock fragments: micaceous. Left = plane-polarized light, right = cross-polarized light.
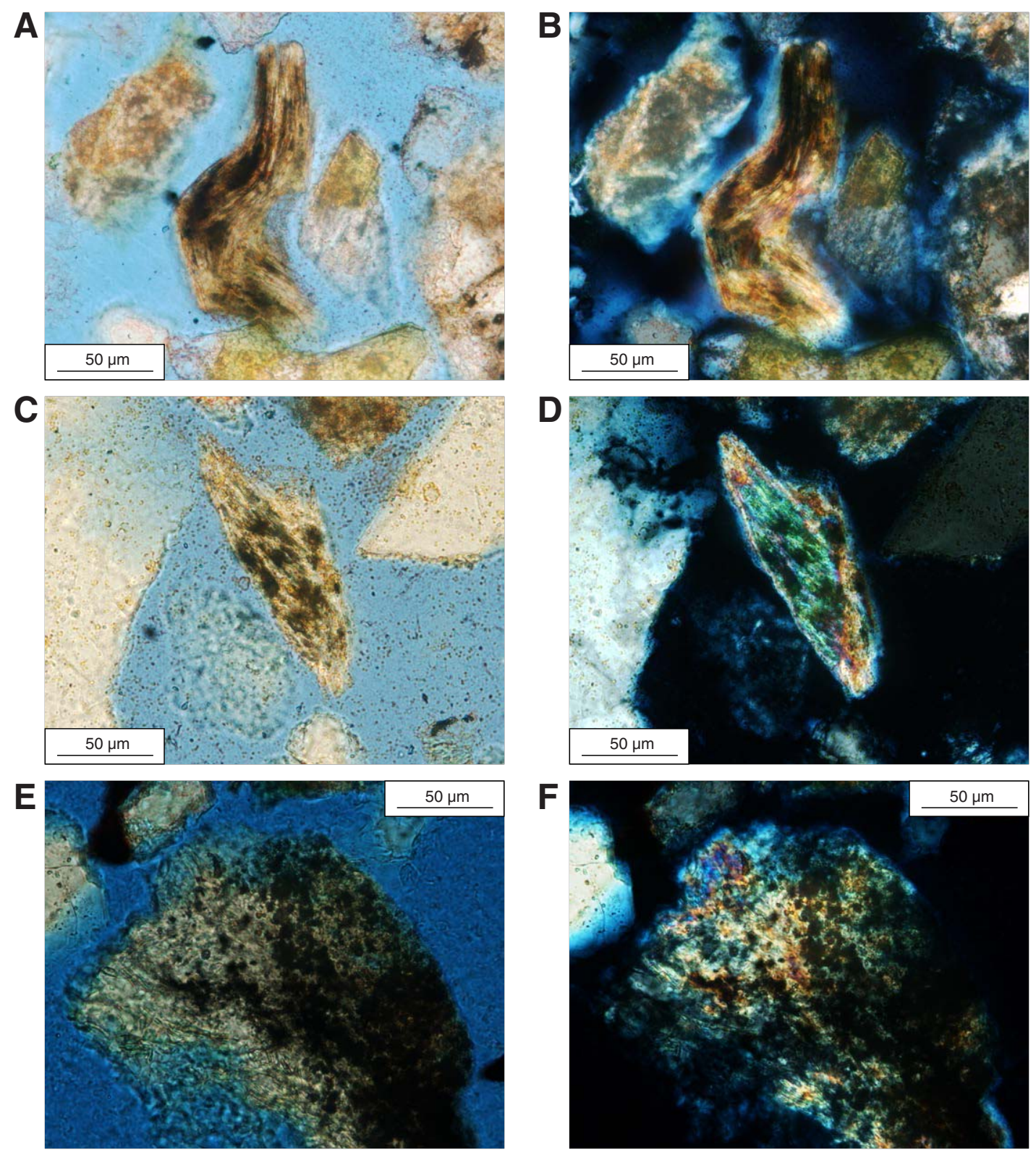
Figure F23. Metamorphic rock fragments: chlorite schists. E, F. Alteration has obscured individual chlorite crystals. Left $=$ plane-polarized light, right $=$ cross-polarized light.
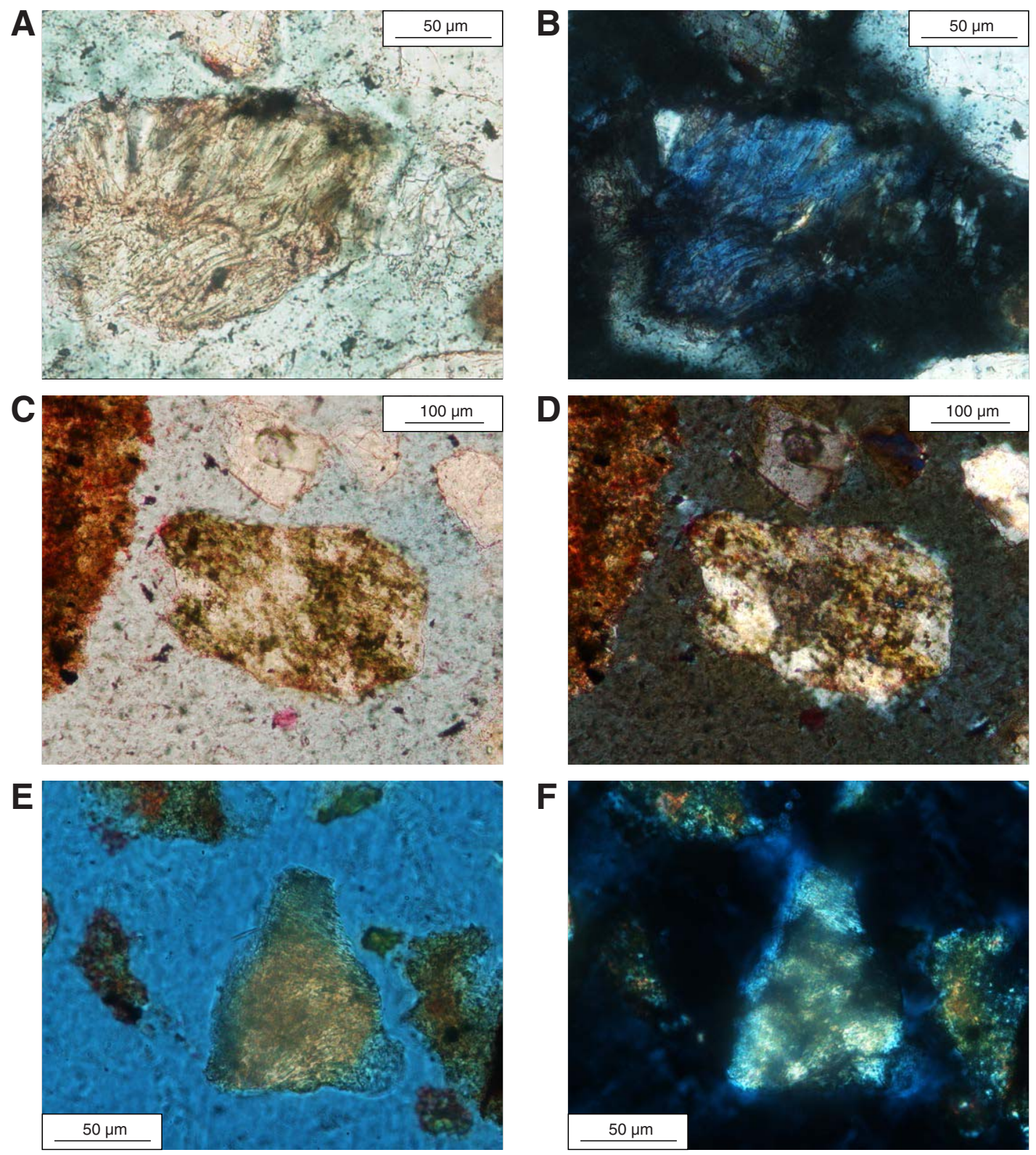
Figure F24. Metamorphic rock fragments: epidote-rich. Left $=$ plane-polarized light, right $=$ cross-polarized light.
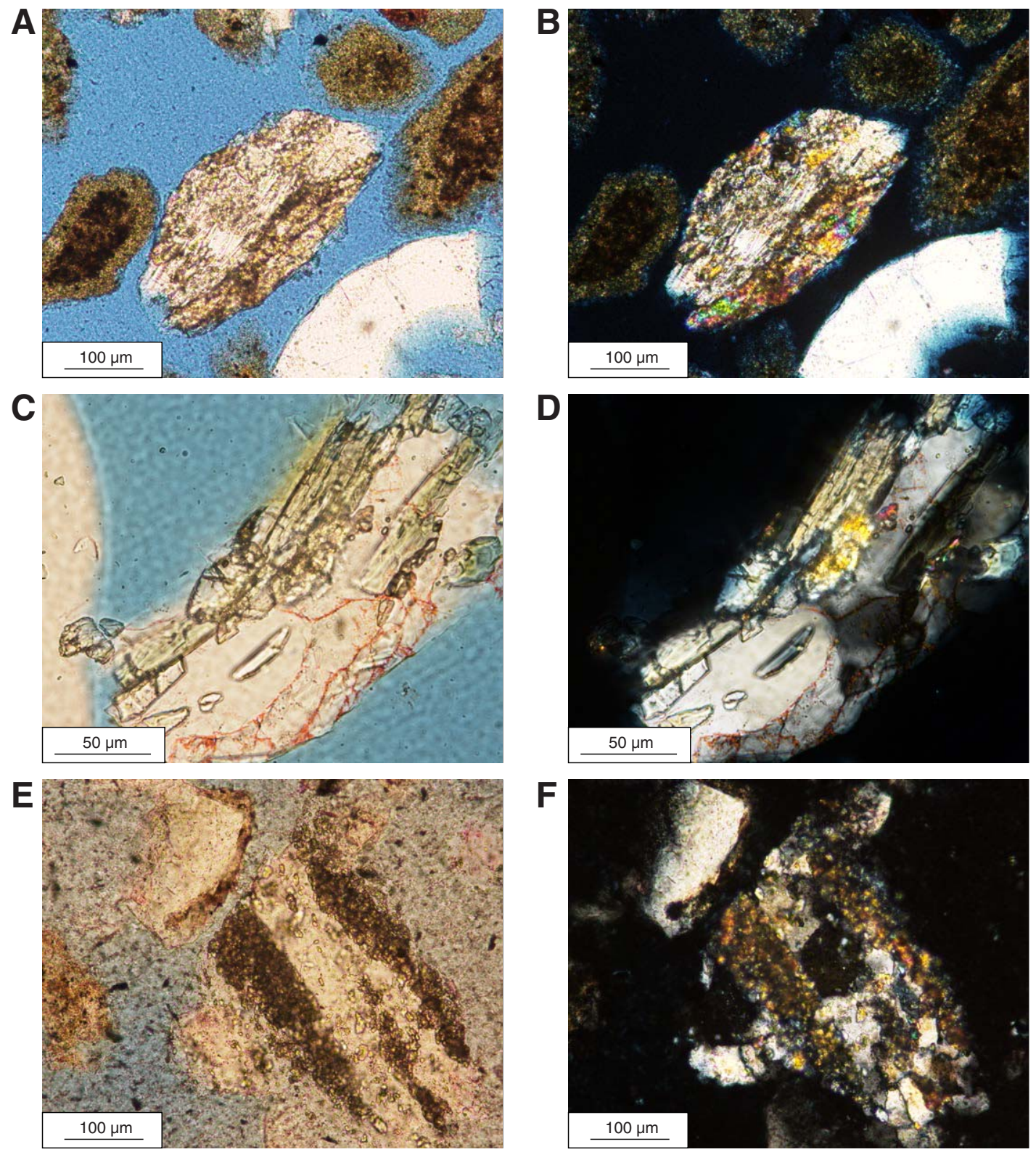
Figure F25. Metamorphic rock fragments. A, B. Feldspar-rich, foliated. C, D. Quartz-carbonate-mica aggregate, nonfoliated. Lack of foliation would also be consistent with the alternative interpretation of carbonate-altered plutonic rock fragments. E, F. Low-grade metamorphic rock fragment (slate) or, alternatively, a fissile silty mudstone. Left $=$ plane-polarized light, right $=$ cross-polarized light .
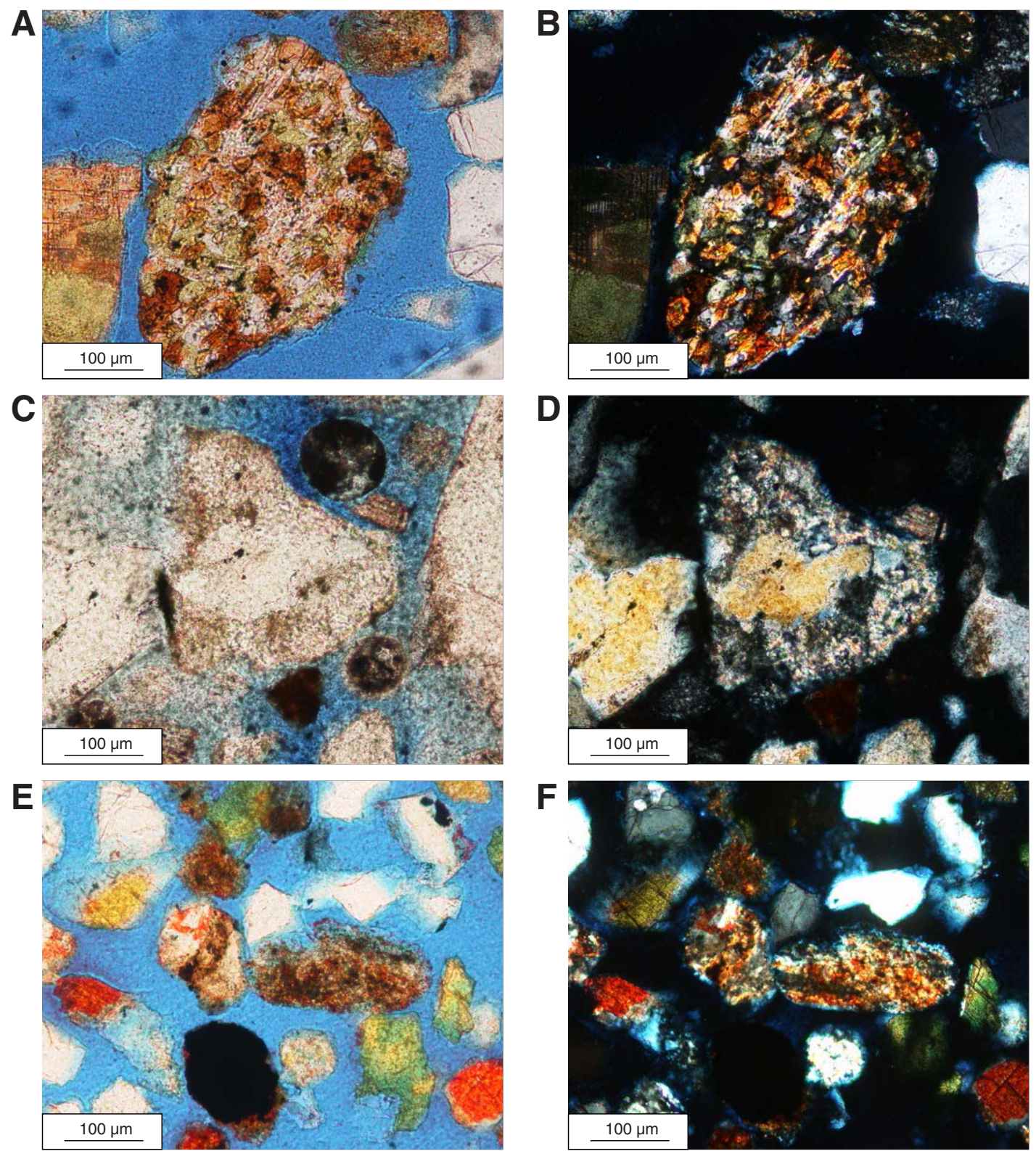
Figure F26. Artifacts: undisaggregated silty mud grains. This interpretation is supported by the size of these fragments, which far exceeds the sizes of the dominant grains in this sediment. Component grains within these large aggregates are also equivalent in size to the surrounding particles. Left $=$ plane-polarized light, right $=$ cross-polarized light.
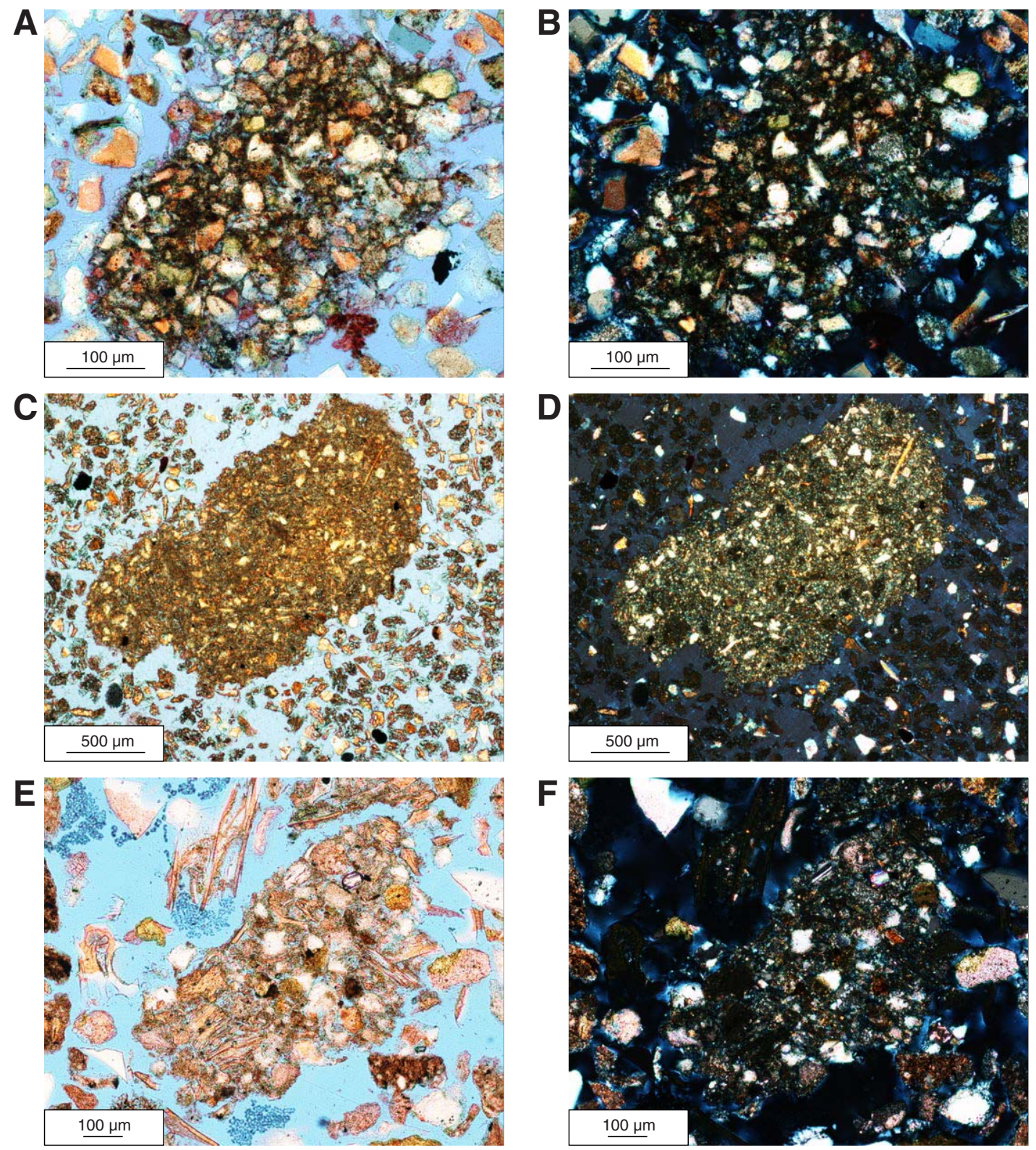
Figure F27. Artifacts: postdrilling sulfate precipitates. Gypsum saturation is not normally expected in the sulfate-poor fluids of the Nankai margin (see fig. F10 in Milliken et al. [2012] for further explanations). Left = plane-polarized light, right $=$ cross-polarized light.
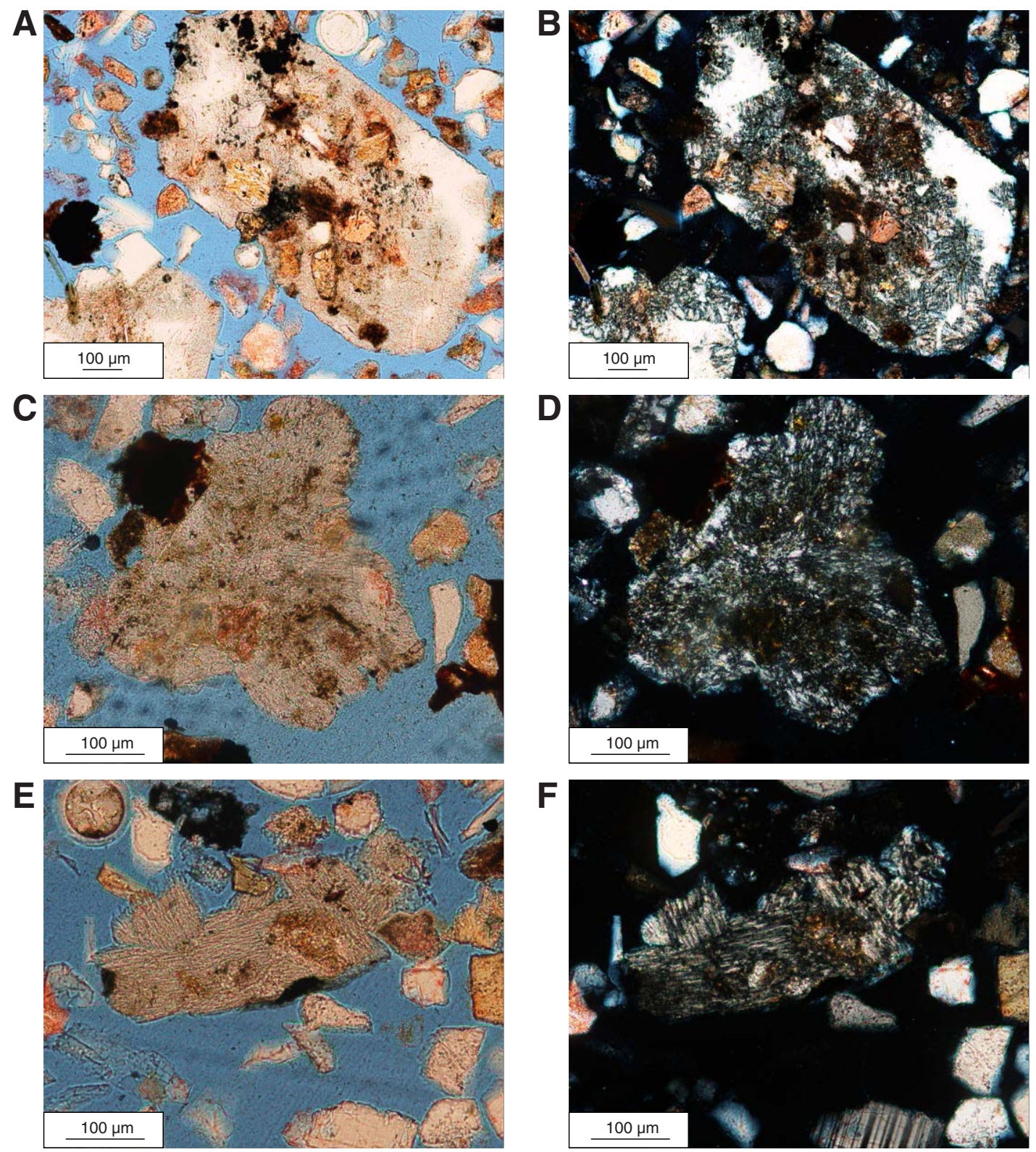
Table T1. Photographed grains shown in figures. (Continued on next page.)

\begin{tabular}{|c|c|c|c|}
\hline Figure & Lithic grain type & $\begin{array}{c}\text { Sample number/ } \\
\text { Expedition, hole, core, } \\
\text { section, interval }(\mathrm{cm})\end{array}$ & Unit \\
\hline F1A, F1B & SRF (mudstone, clay rich) & 338-C0002F-215-SMW & $\mathrm{V}$ \\
\hline F1C, F1D & SRF (mudstone, clay rich) & $315-C 0002 D-5 H-5,35-37$ & 1 \\
\hline F1E, F1F & SRF (mudstone, clay rich) & 338-C0002L-4X-CC, 36-37.5 & II \\
\hline $\mathrm{F} 2 \mathrm{~A}, \mathrm{~F} 2 \mathrm{~B}$ & SRF (mudstone, clay rich) & 338-C0002F-213-SMW & IV \\
\hline F2C, F2D & SRF (mudstone, clay rich) & 338-C0002L-13X-1, 15-16.5 & ॥ \\
\hline $\mathrm{F} 2 \mathrm{E}, \mathrm{F} 2 \mathrm{~F}$ & SRF (mudstone, clay rich) & 315-C0002D-7H-7, 75-77 & 1 \\
\hline $\mathrm{F} 3 \mathrm{~A}, \mathrm{~F} 3 \mathrm{~B}$ & SRF (mudstone, clay rich) & 338-C0002J-6R-1, 62-63.5 & IV \\
\hline F3C, F3D & SRF (mudstone, clay rich) & 338-C0002F-42-SMW & III \\
\hline F3E, F3F & SRF (mudstone, clay rich) & 338-C0002L-9X-7, 79.5-81 & ॥ \\
\hline $\mathrm{F} 4 \mathrm{~A}, \mathrm{~F} 4 \mathrm{~B}$ & SRF (mudstone, clay rich) & 338-C0002F-58 SMW & IV \\
\hline F4C, F4D & SRF (mudstone, clay rich) & 338-C0002L-16X-5, 64-65 & II \\
\hline $\mathrm{F} 4 \mathrm{E}, \mathrm{F} 4 \mathrm{~F}$ & SRF (mudstone, clay rich) & $315-C 0002 \mathrm{D}-14 \mathrm{H}-4,81-83$ & 1 \\
\hline F5A, F5B & SRF (mudstone, clay rich) & $338-C 0002 K-6 T-3,20-21.5$ & II \\
\hline F5C, F5D & SRF (mudstone, clay rich) & $338-C 0002 K-7 X-3,30-31.5$ & 1 \\
\hline F5E, F5F & SRF (mudstone, clay rich) & 315-C0002D-14H-4, 81-83 & I \\
\hline F6A, F6B & SRF (mudstone, silt rich) & 338-C0002F-58-SMW & IV \\
\hline F6C, F6D & SRF (mudstone, silt rich) & 338-C0002F-68-SMW & IV \\
\hline F6E, F6F & SRF (mudstone, silt rich) & 338-C0002F-58-SMW & IV \\
\hline F7A, F7B & SRF (mudstone, silt rich) & 338-C0002F-233-SMW & $\mathrm{V}$ \\
\hline F7C, F7D & SRF (mudstone, silt rich) & $338-C 0002 K-6 T-3,20-21.5$ & II \\
\hline F7E, F7F & SRF (sandstone) & 338-C0002F-77-SMW & IV \\
\hline F8A, F8B & SRF (argillaceous chert) & 315-C0002B-63R-1, 74-76 & IV \\
\hline F8C, F8D & SRF (argillaceous chert) & 338-C0002F-120-SMW & IV \\
\hline F8E, F8F & SRF (argillaceous chert) & 338-C0002F-161-SMW & IV \\
\hline F9A, F9B & SRF (chert) & 338-C0002F-84-SMW & IV \\
\hline F9C, F9D & SRF (chert) & 315-C0002B-1R-3, 125-127 & II \\
\hline F9E, F9F & SRF (chert) & 338-C0002J-6R-1, 62-63.5 & IV \\
\hline F10A, F10B & VRF (felsitic) & 315-C0002D-11H-6, 108-110 & $\mathrm{I}$ \\
\hline F10C, F10D & VRF (felsitic) & 315-C0002D-11H-6, 108-110 & I \\
\hline F10E, F10F & VRF (felsitic) & 338-C0002K-5T-1, 30-31.5 & II \\
\hline F11A, F11B & VRF (felsitic) & 338-C0002F-51-SMW & IV \\
\hline F11C, F11D & VRF (felsitic) & 338-C0002F-77-SMW & IV \\
\hline $\mathrm{F} 11 \mathrm{E}, \mathrm{F} 11 \mathrm{~F}$ & VRF (felsitic) & 338-C0002-F-233-SMW & $\mathrm{V}$ \\
\hline F12A, F12B & VRF (microlitic) & 338-C0002L-22X-7, 39-40 & II \\
\hline F12C, F12D & VRF (microlitic) & 338-C0002F-58-SMW & IV \\
\hline $\mathrm{F} 12 \mathrm{E}, \mathrm{F} 12 \mathrm{~F}$ & VRF (microlitic) & 338-C0002-F-233-SMW & V \\
\hline F13A, F13B & VRF (lathwork) & $315-C 0002 D-8 H-2,27-29$ & I \\
\hline F13C, F13D & VRF (lathwork) & 338-C0002F-42-SMW & III \\
\hline F13E, F13F & VRF (lathwork) & 315-C0002B-63R-1, 74-76 & IV \\
\hline F14A, F14B & VRF (trachytic lathwork) & $315-C 0002 B-59 R-1,33-35$ & IV \\
\hline F14C, F14D & VRF (trachytic lathwork) & 338-C0002F-58-SMW & IV \\
\hline $\mathrm{F} 14 \mathrm{E}, \mathrm{F} 14 \mathrm{~F}$ & VRF (trachytic lathwork) & 338-C0002F-98-SMW & IV \\
\hline F15A, F15B & VRF (pumice) & $338-C 0002 L-6 X-6,26-28$ & II \\
\hline F15C, F15D & VRF (pumice) & 315-C0002B-14R-1, 112-114 & II \\
\hline F15E, F15F & VRF (pumice) & 315-C0002B-59R-1, 33-35 & IV \\
\hline F16A, F16B & PRF & $315-\mathrm{C} 0002 \mathrm{D}-8 \mathrm{H}-2,27-29$ & I \\
\hline F16C, F16D & PRF & 315-C0002B-14R-1, 112-114 & II \\
\hline $\mathrm{F} 16 \mathrm{E}, \mathrm{F} 16 \mathrm{~F}$ & PRF & 338-C0002J-6R-1, 62-63.5 & IV \\
\hline F17A, F17B & PRF & 338-C0002F-90-SMW & IV \\
\hline F17C, F17D & PRF & 338-C0002F-209-SMW & IV \\
\hline F17E, F17F & PRF & 338-C0002F-213-SMW & IV \\
\hline F18A, F18B & PRF (quartz-K-feldspar intergrowth) & $338-C 0002 K-3 T-C C, 25.5-27$ & II \\
\hline F18C, F18D & PRF (quartz-K-feldspar intergrowth) & 338-C0002K-5T-1, 30-31.5 & II \\
\hline $\mathrm{F} 18 \mathrm{E}, \mathrm{F} 18 \mathrm{~F}$ & PRF (quartz-K-feldspar intergrowth) & 338-C0002L-16X-5, 64-65 & II \\
\hline F19A, F19B & PRF & $338-C 0002 K-3 T-C C, 25.5-27$ & II \\
\hline F19C, F19D & PRF & 315-C0002B-63R-1, 74-76 & IV \\
\hline F19E, F19F & PRF & 338-C0002F-51-SMW & IV \\
\hline F20A, F20B & MRF (quartz rich) & 338-C0002K-11X-4, 10-11.5 & II \\
\hline F20C, F20D & MRF (quartz rich) & 338-C0002L-24X-6, 67-68 & II \\
\hline F20E, F20F & MRF (quartz rich) & 338-C0002J-6R-1, 62-63.5 & IV \\
\hline F21A, F21B & MRF (quartz-mica rich) & 338-C0002F-51-SMW & IV \\
\hline F21C, F21D & MRF (quartz-mica rich) & 338-C0002F-58-SMW & IV \\
\hline F21E, F21F & MRF (quartz-mica rich) & 338-C0002F-120-SMW & IV \\
\hline F22A, F22B & MRF (micaceous) & $315-C 0002 D-5 H-5,35-37$ & I \\
\hline F22C, F22D & MRF (micaceous) & 338-C0002K-11X-4, 10-11.5 & II \\
\hline $\mathrm{F} 22 \mathrm{E}, \mathrm{F} 22 \mathrm{~F}$ & MRF (micaceous) & 338-C0002F-182-SMW & IV \\
\hline F23A, F23B & MRF (chlorite rich) & 338-C0002F-174-SMW & IV \\
\hline F23C, F23D & MRF (chlorite rich) & 338-C0002F-199-SMW & IV \\
\hline
\end{tabular}


Table T1 (continued).

\begin{tabular}{llll}
\hline \multicolumn{1}{c}{ Figure } & \multicolumn{1}{c}{ Lithic grain type } & \multicolumn{1}{c}{$\begin{array}{c}\text { Sample number/ } \\
\text { Expedition, hole, core, } \\
\text { section, interval (cm) }\end{array}$} & Unit \\
\hline F23E, F23F & MRF (chlorite rich) & $338-C 0002 F-213-S M W$ & IV \\
F24A, F24B & MRF (epidote rich) & $338-C 0002 F-68-S M W$ & IV \\
F24C, F24D & MRF (epidote rich) & $338-C 0002 F-98-S M W$ & IV \\
F24E, F24F & MRF (epidote rich) & $338-C 0002 F-110-S M W$ & IV \\
F25A, F25B & MRF (other) & $338-C 0002$ J-6R-1, 62-63.5 & IV \\
F25C, F25D & MRF (other) & $315-C 0002 B-63 R-1,74-76$ & IV \\
F25E, F25F & MRF (other) & $338-C 0002 F-250-S M W$ & V \\
F26A, F26B & Artifact (undisaggregated mud) & $338-C 0002 L-9 X-7,79.5-81$ & II \\
F26C, F26D & Artifact (undisaggregated mud) & $338-C 0002 L-13 X-6,71-72.5$ & II \\
F26E, F26F & Artifact (undisaggregated mud) & $315-C 0002 B-14 R-1,112-114$ & II \\
F27A, F27B & Artifact (sulfate precipitate) & $338-C 0002 L-19 X-7,06-07$ & II \\
F27C, F27D & Artifact (sulfate precipitate) & $338-C 0002 L-20 X-C C, 46-47$ & II \\
F27E, F27F & Artifact (sulfate precipitate) & $338-C 0002 L-20 X-C C, 46-47$ & II \\
\hline
\end{tabular}

$\mathrm{SRF}=$ sedimentary lithic fragment, $\mathrm{VRF}=$ volcanic lithic fragment, $\mathrm{PRF}=$ plutonic lithic fragment, $\mathrm{MRF}=$ metamorphic lithic fragment. 